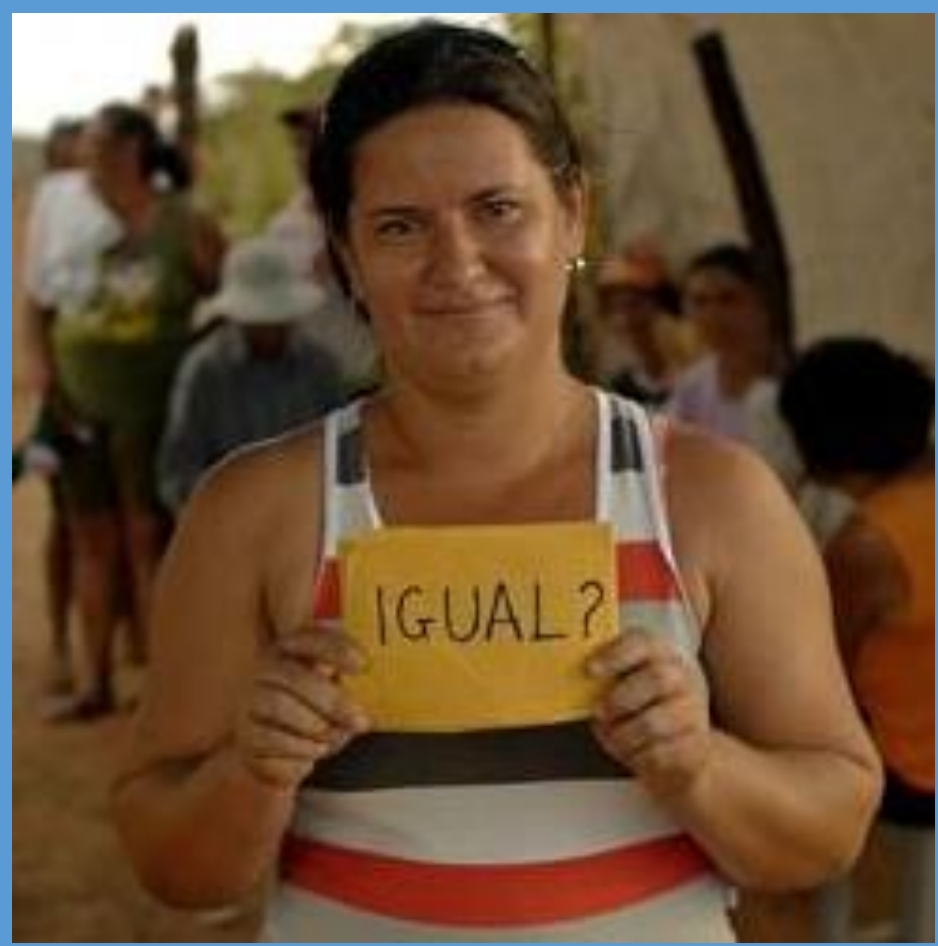

\title{
A Snapshot of Gender in
} Brazil Today

Institutions, Outcomes, and a Closer Look at Racial and Geographic Differences 


\section{A Snapshot of Gender in Brazil Today: Institutions, Outcomes, and a Closer Look at Racial and Geographic Differences}

August 2016

This document was written by Renata Gukovas (Research Analyst, GPVDR), Miriam Müller (Social Scientist, GPVDR), Ana Claudia Pereira (Consultant, GPVDR), and Maira Emy Reimão (Consultant, GPVDR) and edited by John Burgess (Consultant). Valuable feedback was received from peer reviewers Alberto Costa (Senior Social Development Specialist, GSURR) and Maria Beatriz Orlando (Lead Social Development Specialist, GSUGL), as well as Jonna Lundvall (Social Scientist, GPVDR), Stephanie Kuttner (Consultant, GSURR), Candyce Rocha (Senior Communications Officer, LCREC), and Aude-Sophie Rodella (Senior Economist, GWASP). The team is grateful for the guidance and support received from Martin Raiser (Country Director Brazil), Oscar Calvo-Gonzalez (Practice Manager, Poverty Global Practice), Pedro Olinto (Program Leader Brazil) and Boris Utria (Operations Advisor, Brazil) and for the impeccable support provided by Cristina Cifuentes (Program Assistant, GPVDR). 


\section{Contents}

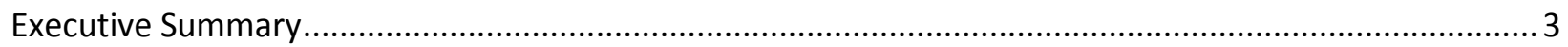

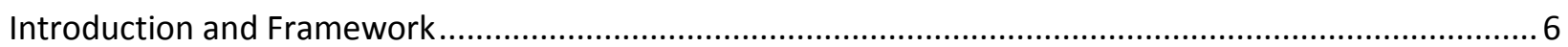

Leading the Way to Gender Equality: Institutions, Public Policies, and Legal Framework...........................7

Creating Institutions and a Public Policy Framework for Women ................................................8

Government Institutions - National and State Secretariats for Policies for Women ......................... 8

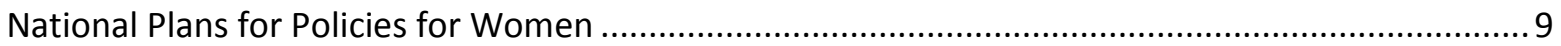

Legal Advances and the Implementation of Specific Public Policies for Women ..............................10

Public Policies on Women's Health..................................................................................................... 10

Strengthening the Rights of Domestic Workers ...................................................................... 11

Legal Advances to Prevent and Protect from Gender-Based Violence.............................................. 12

Other Programs and Policies that Support Women ..................................................................... 14

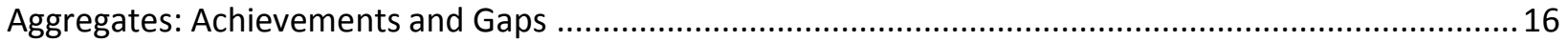

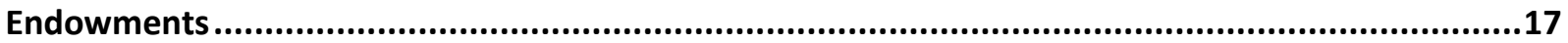

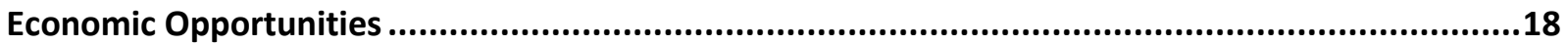

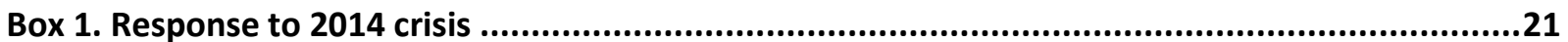

Box 2. Household composition across the income distribution....................................................25

Box 3: "Nem-nems" in Brazil - A gendered perspective on economic and educational disengagement among youth (evidence from qualitative research by Machado and Müller, forthcoming)..............28

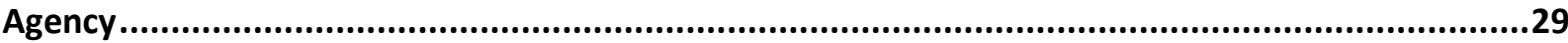

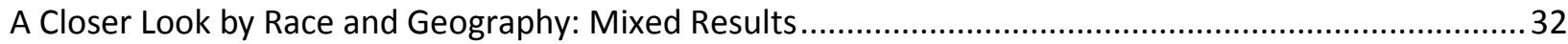

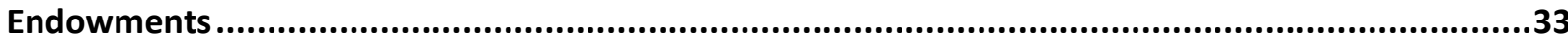

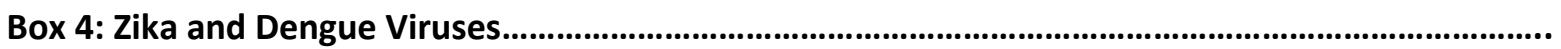

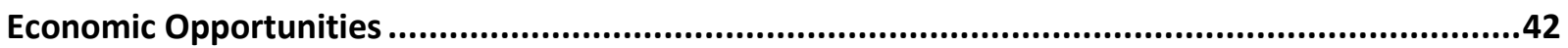

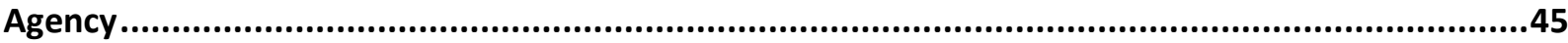

Conclusion: For Further Progress, Address Disparities among Women .................................................50

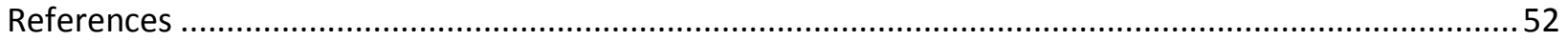

Annex: Number of Specialized Services for Victims of Domestic Violence by State and Type, 2013..........58 


\section{Executive Summary}

Brazil has made great strides in gender equality in the past two decades, as evidenced by its political commitment to policies for women, legal framework on gender-based violence (GBV), and improvements in women's endowments. While many governments voice a commitment to the issue, Brazil's has taken concrete actions to integrate gender equality into the broader policy-making agenda in a participatory manner and has achieved substantial advances in women's education and health and equality before the law. Brazilian women now even outperform men in various education indicators.

This report details progress Brazil has made on reducing gender inequality, highlights persisting gapsparticularly in race/ethnicity and geographic differences-and points to areas for further work.

Major achievements to date include:

- The creation of the Secretariat for Policies for Women (SPM) under the Presidency of the Republic in 2003 and similar institutions at the state level. SPM is charged with mainstreaming gender equality and, along with several partners, outlining the nation's course for improving gender equality through National Plans of Policies for Women, which are carried out in a participatory process with civil society representatives. All states have created similar specialized government institutions for mainstreaming gender equality.

- The Government of Brazil's commitment to addressing domestic violence through internationally innovative policies and legal frameworks. This is evidenced by the enactment of the Maria da Penha Law (2006), ${ }^{1}$ the launch of the Pacto Nacional pelo Enfrentamento da Violência Contra as Mulheres I and II (National Pact for Combating Violence Against Women I and II) and the creation of the program Mulher Brasileira-Viver Sem Violencia (Brazilian WomanLiving Free of Violence), which includes the establishment of Casas da Mulher Brasileira (Brazilian Women's Houses).

- Closing (and in some cases even reversing) the gender gap in education. Educational attainment is consistently increasing for both men and women, and the youth literacy rate (15-24-year-olds) has reached 98 percent for males and 99 percent for females, up from 84 percent in 1980. Currently, close to two-thirds of each year's graduates from tertiary institutions are women.

- Substantial improvements to maternal health. The maternal mortality rate in Brazil fell from 120 per 100,000 live births in 1990 to 69 in 2013. Currently 98 percent of births are attended by skilled personnel, compared to 88 percent in the mid-1990s.

Progress has been weaker, however, in the areas of women's economic opportunities and agency. While Brazil has made clear progress towards gender equality in education and health, outcomes relating to women's economic opportunities and agency (i.e., the capacity to make decisions and take control over one's life projects) lag behind.

Moreover, aggregate advances by women often mask racial or geographic differences in every dimension of gender equality. Even in areas where progress has been made on average, large groups of

\footnotetext{
${ }^{1}$ The Maria da Penha law (2006) has been internationally recognized as one of the most innovative laws on domestic violence worldwide. It is mentioned as a "significant legal advance at the national level" in the UN's Progress of the World's Women 2010.
} 
women are being left behind due to their racial, ethnic or geographic identities. And where inequalities do remain, these same women face disadvantages for being female as well as those brought about by their other identities. The following examples call for lifting the veil on aggregate outcomes and taking differences among women into account when considering gender equality and policies for achieving it:

- Racial and geographic inequalities in education persist despite aggregate improvements. Girls 13-16 years of age in the Southeast and South are more likely to attend school than those in the North, Northeast, or Center-West regions. Moreover, while women over the age of 19 are more likely to attend school than their male counterparts within each racial group, white young adults attend school at higher rates than Afro-Brazilians. In 2013, the university enrollment rate for AfroBrazilians was less than half that of whites (10.8 percent versus 23.8 percent), despite the adoption of quotas for Afro-descendants and indigenous people in public universities.

- Maternal health is similarly marked by racial inequalities. Of the 1,465 maternal deaths registered by the Ministry of Health in 2014, 65 percent were Afro-Brazilian women and 30 percent were white women. Likewise, differences in access to prenatal care are evident: threequarters of pregnant white women receive seven or more prenatal visits, compared to roughly half of pregnant Afro-descendant women and only a quarter of pregnant indigenous women. ${ }^{2}$

- Over the past decade, gender gaps in labor force participation and employment in Brazil have changed little, signaling persistent obstacles to equitable access to economic opportunities. Female labor force participation (LFP) and employment rose only slightly from 54 percent in 1995 to 59 percent in 2014, and the share of employed women moved from 50 percent to 54 percent over the same period.

- Gender wage gaps remain wide in Brazil compared to regional averages and are further marred by racial inequality. ${ }^{3}$ Women's hourly wages are lower than those of men, a gap that is largest among the most educated. Nevertheless, wages paid to Afro-Brazilian women are lower than those paid to men as well as white women with the same education level. On average, AfroBrazilian women earn 7.7 BRL per hour, compared to 12.5 BRL for white women and 15.6 BRL for white men. Among those who have completed secondary school, Afro-Brazilian women earn wages that are less than half the wages of white men.

- The Brazilian adolescent fertility rate has steadily decreased since 2000, but remains high and reveals important geographic differences. The percentage of women aged 15-19 who had a live birth in 2013 compared to all women in that age group is highest in the North, where one in five women in that age group had a live birth, followed by the Northeast. Nationally, 10.5 percent of women 15-19 living in urban areas have had at least one child, compared to 13.2 percent of those in rural areas. In the North, the shares are 14.9 percent in urban and 18.9 percent in rural areas. The Southeast, in contrast, has not only a lower overall prevalence of teenage pregnancy, but also a smaller rural/urban gap, as 9.3 percent of 15-19-year-old women in urban areas and 10.0 percent of those in rural areas report having had at least one child.

\footnotetext{
${ }^{2}$ Brasil. Secretaria de Políticas para as Mulheres da Presidência da República: Relatório Anual Socioeconômico da Mulher 2014 (RASEAM 2014). Brasília-DF: SPM, 2015

${ }^{3}$ World Bank 2012b: Women earned 71 percent of their male counterparts' pay in 2010, according to World Bank calculations. This was among the largest wage gaps for Latin America and Caribbean countries observed at that time.
} 
It is also worth noting that gender dynamics can be detrimental to men as well. In Brazil in particular, continuing underperformance in school by men (specifically Black/pardo males) has grave implications for development. Similarly, men are heavily over-represented as victims of gang violence and homicide

Although the Government of Brazil has demonstrated a political commitment to protecting women's agency and reducing gender-based violence, continuing violence demands further action, and outcomes so far are uneven across the country. About 40 percent of Brazilian women have experienced physical, sexual, or psychological gender-based violence at least once in their lives, ${ }^{4}$ and women are more likely than men to have been a victim of violence perpetrated by a person they know. Concerning regional differences, the homicide rate against women increased by over 70 percent in both the North and Northeast between 2003 and 2013, and only the Southeast registered a decline during that period. Indigenous women are particularly vulnerable, facing a homicide rate almost twice as high as the average. Furthermore, a recent parliamentary investigation on GBV revealed that implementation of the Maria da Penha Law and the service network to support and protect female victims of violence has been very mixed, with limited reach outside urban areas, and hindered by budget constraints and lack of political will at the local level.

Tackling racial and geographic inequalities is critical for reaching gender equality, as it is certainly harder-and in some instances impossible - to raise aggregates of female progress substantially if large sub-groups of women lag behind. Taking the disadvantages faced by sub-groups of women into account is important not only in the design of policies and projects, but also in properly defining the goals for gender equality in Brazil. It would be a disservice to large swaths of the population to only set targets for women on average when non-white women and those living in the northern parts of the country are systematically below the average.

In light of the Government of Brazil's commitment to reducing gender inequality and the substantial but uneven advances achieved over the last few decades, this document looks at gender equality in the country both in terms of formal institutions and outcomes. It is structured around the World Development Report 2012 framework, which holds that gender equality is the result of gains in three dimensions-endowments (outcomes related to education, health and/or physical assets), economic opportunities (outcomes pertaining to jobs, land, agricultural production, technology, or market access), and agency (the ability to make choices to achieve desired outcomes, including voice in decision making). These three dimensions are dependent on interactions between four types of institutions: households, formal institutions, markets, and informal institutions (such as gender roles, beliefs, and social norms). In applying this framework to the concrete progress made in Brazil in recent decades, the document starts off with advances in formal institutions. The document follows with discussion on the endowments, economic opportunities, and agency of Brazilian women, first in aggregate form and then disaggregated by ethnicity/race or geographic area.

\footnotetext{
${ }^{4}$ Fundação Perseu Abramo. Violência contra a Mulher na Esfera Pública e Privada. São Paulo: Fundação Perseu Abramo; SESC, 2010.
} 


\section{Introduction and Framework}

Brazil has made substantial advances in gender equality over the last two decades. Institutional advances include the creation of a Secretariat for Policies for Women (SPM) and the highly participatory design of National Plans for Policies for Women. Brazil has closed the female-male gap in education, improved maternal health, and reduced teenage pregnancy. Other indicators, however, have not shown similar gains. Female labor force participation and employment, for instance, have been constant over the last decade, and the share of female representatives in government remains well below the regional benchmark.

The purpose of this document is to inform World Bank operations and strategy (mainly the Country Partnership Framework process). It is a resource to help Brazil project teams and leaders of the Country Management Unit apply a gender lens to development challenges in the country. Addressing and narrowing gender gaps is not only a Bank mandate, but a key contribution to poverty and inequality reduction (see World Bank 2012). The note offers readers a brief description of the current principal challenges to gender equality in the country. As we demonstrate, several of these issues are better understood when race or geography is also taken into account, so disaggregated data is presented when available. This approach is also in line with the World Bank's predominantly state-level operational engagement with Brazil.

The analysis in this document is structured around the conceptual framework proposed by the 2012 World Development Report on Gender Equality and Development (World Bank 2012a). The WDR 2012 framework argues that progress in gender equality is a result of gains in three dimensionsendowments (outcomes related to education, health and/or physical assets), economic opportunities (outcomes pertaining to jobs, land,

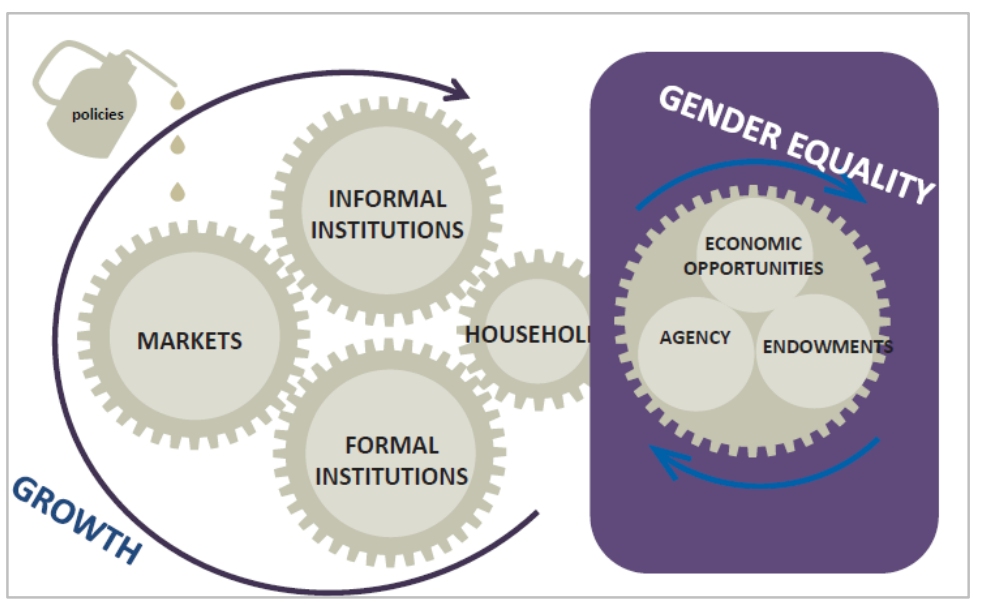
agricultural production, technology, or market access), and agency (the ability to make choices to achieve desired outcomes, including voice in decision making). These three dimensions are dependent on interactions between four types of institutions: households, formal institutions, markets, and informal institutions (such as gender roles, beliefs, and social norms).

The note starts with an overview of the principal institutional changes regarding gender equality experienced in Brazil over the last two decades: the creation of government institutions and policies and legal advances. This progress in formal institutions is closely linked to the three dimensions of gender equality, as discussed in the WDR 2012, reflecting improvements and leading to further gains in endowments, economic opportunities, and agency for women. Of the four institutions highlighted by the WDR, the current report's focus on formal institutions is due to Brazil's unique progress in this dimension 
over the last two decades, which has placed it at the international forefront in terms of policies and legal frameworks for supporting gender equality.

After a discussion on the formal institutional landscape in Brazil, the document analyzes endowments, economic opportunities, and agency through two different lenses-by aggregates and by racial and/or geographic differences. As detailed here, gender is inherently intertwined in Brazil with race and geography, as positive aggregate outcomes may hide inequalities among women and, just as importantly, further progress will likely be hindered by gaps between sub-groups of women.

Policies must take the intersection between gender and race or geography into account if they are to fully address obstacles to gender equality. These policies include measures aimed at employment, teen pregnancy, and gender-based violence.

Finally, the concept of intersectionality has made important contributions to gender analysis as evidenced in Tas, Reimao, and Orlando (2013) and complements the analytical framework applied in this note. As those authors show, this approach seeks to understand and analyze gender in combination with other identities. Intersectionality posits that the intersection of identities produces different experiences and relations when comparing different groups, affecting the interactions, wellbeing outcomes, and social structures that govern their relations. The purpose of the last section of this note is to identify how the intersection of gender, ethnicity, and location of residence are associated with systematic welfare disparities across groups. "The presence of such gaps can point to cumulative disadvantages that exclude individuals and groups who possess multiple identities from certain outcomes," the three authors note.

\section{Leading the Way to Gender Equality: Institutions, Public Policies, and Legal Framework}

\section{Brazil ratified the UN Convention for the Elimination of Discrimination Against Women (CEDAW) ${ }^{5}$ (1984)} and its Optional Protocol ${ }^{6}$ (2002). The recommendation of the CEDAW Committee to consecrate and guarantee in law the principle of equality between men and women is observed in the Federal Constitution of 1988. The Constitution, especially in its Article 5, emphasizes equal rights and obligations for women and men.

The Brazilian legal system has sought to harmonize legislation to assure compliance with constitutional principles on gender equality. The Brazilian Civil Code (updated in 2003) embraces the constitutional principle of equality between women and men and incorporates equality in marital rights and duties

\footnotetext{
${ }^{5}$ With reservations against Article 29. Under this article of CEDAW, two or more state parties can refer disputes about the interpretation and implementation of CEDAW to arbitration, and if the dispute is not settled, it can be referred to the International Court of Justice. This procedure is subject to a large number of reservations and has never been used (http://www.un.org/womenwatch/daw/cedaw/protocol/why.htm).

${ }^{6}$ The Optional Protocol allows parties to recognize the authority of the CEDAW Committee to consider complaints from individuals.
} 
(Article $226 \S 5$ ). Articles in which the ages of women and men were different have been repaired to make the ages equal, ${ }^{7}$ thereby establishing a balance between the sexes.

The women's rights agenda has gained strength in Brazil since democratic government was reestablished in the late 1980s. Feminist and women's movements successfully advocated for the inclusion of gender equality principles in the 1988 Constitution, as well as for legal changes aimed at enforcing such principles. Women's movements in the country reflect the diversity and inequalities among women-feminists, lesbians, labor union women, black women, domestic workers, women living in poor communities, rural women, and indigenous women. ${ }^{8}$ Indeed, all these groups have played a major role in the women's rights' agenda. They are diverse in terms of composition, goals, and strategies used for advancing their objectives in Brazilian society and government.

Activist organizations and the government have engaged in increasing dialogue in recent decades, with the state playing a strategic role in intervention and advancing women's rights. The high level of engagement of civil society in Brazil has been crucial to developing a so-called "feminist agenda of public policies" (Alvarez 1999). This agenda is organized around key thematic axes: ensuring the universal right to non-sexist education, health and welfare, land rights, and housing; eradicating violence against women (including abuse, harassment, and sexual exploitation); countering racism and lesbophobia; promoting inclusive development frameworks; strengthening sexual and reproductive health and rights (including the legalization of abortion); and recognition of non-traditional family arrangements (Bairros 1995 and Soares 1998). ${ }^{9}$

\section{Creating Institutions and a Public Policy Framework for Women}

The creation of the Secretariat for Policies for Women (SPM) was a turning point in Brazil's commitment to women's rights. It empowered a body within the federal government with a mandate to create and enforce policies for gender equality, and led to the design and implementation of National Plans for Policies for Women.

\section{Government Institutions - National and State Secretariats for Policies for Women}

Brazil has made concrete progress in integrating gender equality into government institutions and actions over the last two decades. SPM, created under the Presidency of the Republic in 2003 and

\footnotetext{
7 An exception is found in the retirement age, which still differs between women and men (60 years versus 65 ). See World Bank: Women, Business and the Law database.

${ }^{8}$ Indigenous women face stark obstacles when pursuing political action and access to information. UN Women-Brazil is currently working with indigenous women leaders to conduct a national consultation and ultimately establish an indigenous women's national platform.

${ }^{9}$ Feminist and women's rights organizations have also mobilized many public demonstrations in Brazil. The Marcha das Margaridas ("March of the Daisies"), for instance, is a major demonstration headed by labor union and rural women demanding social justice and gender equality. As of August 2015, five of these demonstrations had taken place. Furthermore, since 2011, "slut walks" have been staged on a yearly basis in many state capitals. A National Black Women's Walk took place in 2015 in Brasilia, and a Festival of Afro-Latin-American and Caribbean Women has gained international recognition, with the participation of internationally prominent activists, artists, and intellectuals. Public demonstrations are accompanied by growing cyber-activism, of which Blogueiras Negras and Blogueiras Feministas (black bloggers, feminist bloggers - note: using the female term for blogger) are emblematic.
} 
originally granted ministerial status, advises the Presidency and coordinates with governmental bodies at the federal, state, and municipal levels on issues of gender equality. Through a participatory process extending over a four-year period, it has outlined National Plans of Policies for Women aimed at improving gender status.

The National Council on Women's Rights (Conselho Nacional dos Direitos da Mulher - CNDM), created in 1985 under the Ministry of Justice, was placed under SPM in 2003. It has expanded to include representatives of other areas of government and civil society. The Council is now comprised of 16 members of various departments of the federal government and 21 elected civil society representatives. The head of SPM presides over it. The Council formulates guidelines for the promotion of women's rights and enforces gender-related policies.

The commitment to gender equality has extended to the subnational level. All 26 Brazilian states and the federal district have established specialized governmental institutions for mainstreaming gender equality $^{10}$ (IBGE 2014b). However, the capacity of these institutions at the subnational level varies significantly and several have very limited operational capacity or policy influence. Most states also have state-level councils on women's rights modeled after the CNDM (IBGE 2014a).

However, SPM lost its ministerial status in September 2015 and was merged with the Ministry of Human Rights and Racial Equality, now called the Ministério das Mulheres, Igualdade Racial e Direitos Humanos. This was done as part of a national ministerial reform to cut government spending. Women's groups and feminist organizations decried this action as a setback for gender equality in Brazil.

In 2009, the office of the Procuradoria Especial da Mulher was created in Brazil's lower chamber of Congress, the Chamber of Deputies (Câmara). The office was given the overarching objective of promoting more gender equitable legislation and policy. The Procuradoria is led by a Procuradora who is a sitting member of the Câmara elected every two years by the Women's Caucus (Bancada Feminina) in the chamber. Together with the recently created Procuradoria do Senado, the institution aims to contain efforts to undo legislative advances. But both are facing a difficult political environment (see Implementation Completion Memorandum (ICM) for the IDF Grant to IDF Grant TF-11956 for Strengthening the Capacity of Procuradoria Especial da Mulher - P129617).

\section{National Plans for Policies for Women}

Policies for women in Brazil are the product of a highly participatory process. Four National Conferences on Policies for Women (Conferência Nacional de Políticas para as Mulheres-CNPM) have taken place under the direction of SPM since its establishment (in 2004, 2007, 2011 and 2016), with the participation of women in various levels of government and civil society. The first three conferences each led to a National Plan of Policies for Women (Plano Nacional de Políticas para as Mulheres-PNPM). Prior to the conferences, consultation rounds are held at municipal and regional levels, with the purpose of crafting

${ }^{10}$ Of the 27 Brazilian States and Federal District, 11 installed secretariats with specific women's rights mandates; 10 installed specialized departments under a specific secretariat; four set up secretariats with a broader mandate (including gender); and two installed a specialized sector under the governor's cabinet. 
or strengthening plans of policies for women and institutionalizing gender-related policies. After that, state conferences are convened in order to elect delegates for the conference and, in some cases, draft State Plans of Policies for Women. (Currently, twelve states have adopted their own state plans of policies for women). ${ }^{11}$ The conference then gathers delegates of civil society and local, state, and federal government to debate and vote on a set of guidelines for policies for women. ${ }^{12}$ The conference is responsible for converting these resolutions into a National Plan of Policies for Women.

The most recent national plan (2013-2015) outlines principles, guidelines, and goals for policies for women in Brazil, and is structured into $\mathbf{1 0}$ chapters, reflecting priority areas to be addressed. These are Labor and Economic Autonomy; Education; Health and Sexual and Reproductive Rights; Combating Violence Against Women; Political Participation; Sustainable Development; Land Rights; Culture, Sports, Communication and Media; Combating Racism, Sexism, and Lesbophobia; and Young, Elderly, and Disabled Women. ${ }^{13}$ An Articulation and Monitoring Committee, ${ }^{14}$ gathering most relevant ministries and institutions under SPM's coordination, oversees the plan's implementation. Thirty-two ministries are responsible for at least one action set out by the plan.

\section{Legal Advances and the Implementation of Specific Public Policies for Women}

The heightened commitment by the national government over the last decade to protect women's rights is also reflected in two important legal changes with respect to domestic workers and genderbased violence. GBV is a core area of SPM's work, and places Brazil as a world leader in terms of comprehensiveness of legislation to protect and support female victims of violence.

\section{Public Policies on Women's Health}

The framework for promoting women's health in Brazil covers all stages of the lifecycle. This plan is laid out by the National Policy for Comprehensive Attention to Women's Health ${ }^{15}$ and the Third National Plan of Policies for Women. These documents reaffirm a comprehensive approach to women's health, fostering the idea that health policies should address the multiplicity of women's needs over all stages of life, including reproductive health. These public policy commitments, along with the National Program on Women's Health (Brasil 1983), ${ }^{16}$ are widely acknowledged as taking a broad view of women's health that extends beyond maternal health (Lyra da Fonseca 2008; Costa 1996 and 2006). The National Policy for Comprehensive Attention to Women's Health in particular reiterates not only the national commitment to promoting sexual and reproductive rights, but also establishes guidelines for the care of prevalent

11 The states with Plans of Policies for Women are: Amazonas, Amapá, Bahia, Goiás, Minas Gerais, Mato Grosso do Sul, Pará, Paraíba, Pernambuco, Rio Grande do Norte, and Sergipe e Tocantins (IBGE 2013).

${ }^{12}$ Regulations for the 3rd National Conference of Policies for Women are available at

http://www.spm.gov.br/arquivos-diversos/3a-conferencia-de-politicas-para-as-mulheres/regimento-3aconferencia.pdf.

${ }^{13}$ The current National Plan of Policies for Women is available at:

http://www.spm.gov.br/assuntos/pnpm/publicacoes/pnpm-2013-2015-em-22ago13.pdf.

${ }^{14}$ http://www.spm.gov.br/sobre/a-secretaria/secretaria-executiva/comite-de-articulacao-e-monitoramento-do-

plano-nacional-de-politicas-para-as-mulheres-pnpm

${ }^{15}$ http://www.spm.gov.br/assuntos/saude-integral-da-mulher

${ }^{16}$ It is noteworthy that feminist movements played a pivotal role in demanding and crafting the National Program and the Policy (2004). 
gynecological diseases; for the prevention, detection, and treatment of cervical and breast cancer; for assisting women during menopause; for attending victims of domestic and sexual violence; and for promoting access to healthcare for specific segments of the female population such as incarcerated women (BRAZIL 2004). The Third National Plan of Policies for Women also calls attention to the inequalities between women across race, ethnicity, age, social status, sexual orientation, and disabling conditions.

In 2012, the Federal Government launched the Rede Cegonha (Stork Network) strategy to organize and improve family planning and maternal and child healthcare in the country. The strategy has four components: prenatal; labor and birth; puerperium and newborn health; and logistics. When first released, the strategy employed a maternal and child health framework that was widely criticized by the feminist movement. As a result, the strategy was re-designed in order to adopt a reproductive health framework in which women are seen as rights holders, entitled to humanized healthcare. Rede Cegonha gathers together a number of actions designed to meet Brazil's targets on maternal health in the Millennial Development Goals.

\section{Strengthening the Rights of Domestic Workers}

In Brazil, domestic workers are very common and overwhelmingly female, making the rights of this group an important issue for women's rights generally. Among all Brazilian women aged 20-50, 8.7 percent are employed as domestic workers; among all employed Brazilian women, this share rises to 13.4 percent. The respective percentages for men are 0.7 and 0.8 .

In recent years, domestic workers' organizations and feminist social movements mounted several efforts to secure the same labor rights for domestic workers that are guaranteed for other professional categories. Laws 10,208/2003 and 11,324/2006 reduced the gap and ensured domestic workers greater (though not yet comprehensive) social protection and rights such as job stability for pregnant employees and a 30-day leave. Another important step was the adoption of Convention 189 at the International Labour Conference in Geneva in June 2011. The convention came into force in September 2013 and prohibits any discrimination regarding domestic workers' rights. Although Brazil has not ratified the convention, internal repercussions concerning it reinforced pressure for equal rights for domestic workers.

More recently, in 2013 the National Congress approved the Proposal for Constitutional Amendment (PEC) number 66, which guarantees an array of rights to domestic workers. Upon approval, workers across the country were immediately granted a limitation of 44 working hours per week, with all hours above that counting as overtime with a 50 percent premium in pay. Seven other rights contemplated by the initial proposal-including entitlement to unemployment insurance and extra pay for night workwere granted in May 2015. Though these changes were a victory for domestic workers' and women's rights, the delay by which they were granted and the controversy reflected the resistance of employer organizations and the reliance of so many urban upper- and middle-class households on these workers. 
The lack of formalization of domestic workers remains an important obstacle for realizing these rights. Only 31.8 percent of female domestic workers were formalized in 2013 and the average earning was 626 Brazilian Reais per month, a level that indicates a high degree of vulnerability. ${ }^{17}$

\section{Legal Advances to Prevent and Protect from Gender-Based Violence}

Domestic violence is another key barrier to women's full development in Brazil that must be comprehensively addressed. This was demonstrated by the enactment of the Maria da Penha Law in $2006^{18}$ and the launch of the National Pacts for Combating Violence Against Women I and II (Pacto Nacional pelo Enfrentamento da Violência Contra as Mulheres I e II). Brazil has also invested significantly to suppress domestic violence by expanding the network designed to provide services to victims, protect them, and punish perpetrators. This network includes government institutions and non-governmental organizations, bringing together sectors that include social welfare, justice, public safety, and health. Dedicated institutions in this system include Specialized Police Stations for Women (Delegacia Especializada de Atendimento à Mulher, DEAM), Specialized Centers for Women (Centro Especializado de Atendimento à Mulher, CEAM, which provide services including shelter, psychological support, legal assistances, and help to women to access other services), ${ }^{19}$ and special courts for dealing with domestic violence cases. The network also relies on non-specialized services such as regular police, family courts, shelters, and health providers including Medical-Legal Departments (DML), which are in principle trained and prepared to properly attend to cases of domestic violence. See Annex 1 for an overview of existing services by the Brazilian state.

The Maria da Penha Law is a federal law but the responsibility for its implementation is decentralized to states and municipalities, with no built-in federal enforcement mechanisms or conditionality. While the law has been internationally recognized as one of the most comprehensive legal instruments to

\footnotetext{
17 In 2013, the minimum wage was set at 678 Brazilian Reais per month. The current (2016) minimum wage is 880 Reais.

18 The Maria da Penha Law (2006) has been recognized internationally as one of the most innovative laws on domestic violence worldwide. It is mentioned as a "significant legal advance at the national level" in the UN's Progress of the World's Women 2010. The law is named after Maria da Penha who was a victim of domestic violence by her husband. The case was in court since 1983 and Maria da Penha's husband remained free. In 2001, the OAS's Court of Human Rights criticized the Brazilian government for not taking effective measures to prosecute and convict perpetrators of domestic violence. In response to this, the Brazilian government enacted a law on Domestic and Family Violence under the symbolic name "Maria da Penha Law" (see: http://www.unwomen.org/en/news/stories/2011/8/maria-da-penha-law-a-name-that-changed-

society\#sthash.xQpneapg.dpuf)
}

${ }^{19}$ According to the SPM, CEAMs should provide the "necessary care and attention to help women overcome their situation, contributing to the empowerment of women and rescuing their sense of citizenship." The activities performed by CRAMs (according to the Technical Guidelines) should include: (1) counseling in times of crisis, (2) psychosocial support, (3) legal counseling and advice, (4) preventive actions, (5) professional qualification, (6) articulation of local public and private services integrating the GBV network, and (7) survey of local data on women who face violence. Most cases are referred by Women's Police Stations, although some women come on their own having heard of the facility by word of mouth from friends, neighbors, or other public services. 
address this problem, there are still several bottlenecks regarding its implementation, notably questions of jurisdiction and insufficient funding from states and municipalities.

The creation of the Central Assistance Hotline to Women in $\mathbf{2 0 0 5}$ was another important milestone for strengthening the anti-violence network in Brazil. The hotline (dial 180) provides women with legal and services information. As of 2014, women could also use it to report cases of violence. Complaints filed through this service are forwarded to law-enforcement agencies and to state public prosecutors' offices.

In March 2013, Brazil launched Programa Mulher, Viver sem Violência ("Woman-Living Without Violence"). It provides for the eventual creation of centers called Casa da Mulher Brasileira (House of the Brazilian Woman) in all 26 state capitals and the Federal District, with a goal of integrating services around public security, justice, health, social welfare, counseling, shelter, employment, and income generation. The idea is to offer an environment that can empower women to break out of situations of violence by providing emergency counseling, and immediate protection and support in the houses or though referral to other service providers such as clinics, hospitals, and "safe houses."

The creation of the Casas da Mulher Brasileira started in 2013 and all states except Pernambuco, for which negotiations are still ongoing, have joined the program, with 18 having signed the terms of agreement and chosen a location for building the facilities. So far, however, the service is only fully functioning in two capitals: the first Casa da Mulher Brasileira was inaugurated in February 2015 in Campo Grande, state of Mato Grosso do Sul, and the second in June 2015 in Brasília. When the service was first announced, in March of 2013, the President stated that all units should be functioning by the end of 2014. Nonetheless, problems with public bids and contracting companies have delayed the work. While the federal government commits to fund the building and the initial operation of the centers, local municipalities are supposed to take up responsibility for their maintenance and operational costs within two years.

The model of providing services through Casa da Mulher Brasileira provides for interacting with the existing network of services to prevent and combat violence against women. Concerning health services, it is important to highlight that the Notifiable Diseases Information System (Sistema de Informação de Agravos de Notificação, SINAN) requires mandatory notification of cases of domestic or sexual violence.

The Government of Brazil has also invested in partnerships with local authorities and in mobile units ( 54 buses and five boats) that provide specialized services to women living in rural and remote areas, including social, psychological, health, and legal advice. In addition, there are plans for creating seven new centers providing services (counseling, legal assistance, and reference to the specialized network) to women at strategic points at the country's borders by the end of $2016^{20}$ to address violence, human trafficking, and migration. Three existing border center ${ }^{21}$ will receive additional resources to expand their services.

\footnotetext{
${ }^{20}$ Bonfim (RR), Brasiléia (AC), Corumbá (MS), Jaguarão (RS), Ponta Porã (MS), Santana do Livramento (RS), and Tabatinga (AM) will have land border centers.

${ }^{21}$ Currently, land border centers operate in Foz do Iguaçu (PR), Oiapoque (AP), and Pacaraima (RR).
} 
Extending the services network to cover rural women remains a challenge. Specialized and nonspecialized services within the network are concentrated in urban areas. Even theoretically nationwide services, such as Dial 180, do not reach all parts of the country. At the same time, the number of calls to Dial 180, which covers 70 percent of Brazilian cities, originating from rural areas quadrupled from 2013 to 2014 (Brasil 2015a).

In 2012, the National Congress set up a Parliamentary Investigation Committee on Violence Against Women (CPMI-VCM) to gather information about the phenomenon and evaluate the government's application of existing legal instruments intended to protect Brazilian women. The investigation prompted visits to several service centers and a review of service data and public hearings with women's rights advocates, experts, and authorities. The CPMI-VCM's investigative report recommended changes to the methods of publicizing national plans and better information on public funding, so as to ensure greater transparency and make it possible to trace back the resources designated for preventing and combating violence against women. Limited budgets and frequent lack of political will for implementing the legal commitments were also highlighted in the committee's report.

On March 9, 2015, a day after International Women's Day, Brazil passed legislation addressing femicide in the country. President Dilma Rousseff played a key role in the measure. Women's rights advocates have increasingly applied the concept of femicide to draw attention to the severity of gender-based violence in the country (Segato 2006; Lisboa 2010; Pasinato 2011). In accordance with international law, Brazil's new law recognizes femicide as the act of murdering women because they are women. ${ }^{22}$

Regarding sexual violence, the Secretariat for Policies for Women, the Ministry of Health, and the Ministry of Justice recently began enforcing a new protocol combining evidence collection and care of sexual assault survivors (Portaria Interministerial 288/2015). The protocol establishes a chain of custody for the evidence and eliminates the need for victims to be examined both by health and law-enforcement professionals.

\section{Other Programs and Policies that Support Women}

There are other public programs that operate outside the specialized framework but disproportionately benefit women and reduce gender inequality. Women are the majority of direct beneficiaries of the main public programs on social security and cash transfers in Brazil. They comprise 54 percent of urban beneficiaries and 62 percent of rural beneficiaries of public social security-retirement, pensions, and assistance during illness, accidents, and maternity leave (Brasil 2015b). They are also the main recipients of the Bolsa Familia conditional cash transfer program. Established in 2004, Bolsa Familia ${ }^{23}$ prioritizes women as the recipients of the cash, on grounds that they generally make better financial decisions regarding their families than do men. ${ }^{24}$ In 2014, 55.9 percent of its 33 million beneficiaries were women. ${ }^{25}$

22 "Brazil Femicide Law Signed by President Rousseff." BBC News: Latin American \& Caribbean. Published March 9, 2015. http://www.bbc.com/news/world-latin-america-31810284.

${ }^{23}$ Bolsa Familia benefit amounts vary according to the number, ages and income of family members. Additional benefits are provided to families with children, young people under 17, pregnant women, and nursing mothers.

${ }^{24}$ http://www.mds.gov.br/saladeimprensa/noticias/2011/marco/bravas-mulheres-do-bolsa-familia

${ }^{25}$ Despite women being the main recipients, the whole family is considered the beneficiary. However, women are still overrepresented because female-headed households are over-represented below the poverty line. 
Research has also highlighted the program's potential to increase women's autonomy and empowerment (Pinzani and Rego 2014) and reduce gender-based violence (Perova et al. 2012) and teenage pregnancy (Azevedo et al. 2012).

Similarly, public housing programs such as the Programa de Habitação de Interesse Social ("Social Interest Housing Program") and Minha Casa, Minha Vida ("My House, My Life") have long prioritized female heads of households. According to official data, almost nine in 10 low-income contracts for Minha Casa, Minha Vida are assigned to women. ${ }^{26}$ The program also ensures that women's ownership stakes are protected in case of divorce or separation.

The National Program on Family Agriculture (Programa Nacional de Fortalecimento da Agricultura Familiar, PRONAF) offers a dedicated line of credit to rural women (BNDES 2015). In practice, however, accessing it is quite difficult, because female applicants must submit a technical project for approval, which requires technical knowledge and thus imposes barriers particularly for less-educated women. Some women overcome this by relying on local cooperatives and/or other services to assist in proposal design, but it is clear that this agricultural credit does not generally reach the poorest or least-educated women in rural areas.

Childcare is another service in which access guaranteed by the legal code is greater than what is observed in practice. According to the Brazilian Constitution, all children have the right to public childcare, since it is considered part of childhood education. This right has important implications for women and their labor force participation, as they tend to be their children's primary caretakers. Nonetheless, previous and current policies have not sufficiently addressed the scarcity of childcare facilities. The National Education Plan for 2000-2010 noted the goal of meeting at least 50 percent of the demand for daycare for children ages 0-3 by 2005. The need for childcare was also prominently discussed in President Dilma's campaign for reelection. In 2010, she anticipated the building of six thousand daycare facilities ${ }^{27}$ across the country. Nonetheless, budget execution seems to have been less than 35 percent of the authorized resources in 2012 (CFEMEA 2014). As a result, only 23.3 percent of all children ages 0-3 went to school or daycare in 2013, and the rate is as low as 8.5 percent in rural areas (IBGE 2015). In total, 2.5 million children are currently waiting for a spot in daycare (Observatório do PNE 2015).

In January 2014, the Federal Government published the National Policy of Attention to Women in Situation of Deprivation of Liberty and Ex-Prisoners (Política Nacional de Atenção às Mulheres em Situação de Privação de Liberdade e Egressas do Sistema Prisional - PNAMPE). This policy was in response to a rise in the rate of the incarceration of women. From 2000 to 2012, the Brazilian female prison population increased from 10,122 to 35,039, nearly twice the growth rate of men's imprisonment (Instituto Avante Brasil, 2013). ${ }^{28}$ At the same time, the female population in prison represents only 6.4

\footnotetext{
${ }^{26}$ Caixa Econômica Federal in http://mcmv.caixa.gov.br/mulheres-respondem-por-mais-de-86-dos-contratos-dominha-casa-minha-vida-na-faixa-1/

27 The extension of daycare provision was announced as part of Program for Growth Acceleration (PAC) and of Programa Brasil Carinhoso. (Program Affectionate Brazil)

${ }^{28}$ According to data processed by Instituto Avante Brasil, based on information collected by the National Penitentiary Department (DEPEN). See Instituto Avante Brasil (2013).
} 
percent of the overall imprisoned population. While 60 percent of women are arrested on drug trafficking charges (Brasil 2015b 2014), a sexual division of labor in the drug trade generally delegates women to minor and subordinate trafficking roles such as being "mules" who transport drugs but aren't involved in selling them (Boitex and Pádua 2013). Most female prisoner are young (18 to 29 years), Afro-descendants (61 percent), and have low educational levels (44 percent have not finish elementary school), according to Último Segundo (2014). ${ }^{29}$

\section{Aggregates: Achievements and Gaps}

As with the legal and political advances, Brazil has also secured concrete accomplishments on gender outcomes in all three dimensions-endowments, economic opportunity, and agency-in recent decades in important areas, particularly with respect to endowments. In education, for example, literacy rates have soared and primary school enrollment is close to universal, leaving little space for gender differences. Participation is lower at higher levels of education, but is no longer stacked against women. By some measures, women currently have higher education attainment levels than men. And though Brazil did not meet the Millennium Development Goal on maternal health, it has nonetheless made substantial advances and stands above regional averages.

The leaps in education and health, however, have not brought meaningful changes in economic opportunities for women. In Brazil, female labor force participation and employment are well below those of their male counterparts, and while these ratios are higher than the Latin American average, they have changed little over the last decades. Occupational segregation and gender-biased vocational training remain an obstacle, likely contributing to the gender gap in employment and earnings, as women are concentrated in lower-growth sectors than men.

The legal cornerstone of Brazil's campaign against gender-based violence, the Maria da Penha Law, was enacted in 2006, but its implementation has had limited success, stunting its impact on women's agency. Not only is incidence of violence against women still disconcertingly high, but beliefs and social norms-often including those of workers within the system created for protecting women-oftentimes retain an acceptance of violence. Moreover, not all service points tasked in the protection of womenfrom DEAMs to courts to health centers-are adequately staffed, equipped, or trained for serving female victims of violence (Campos 2016).

The next three sub-sections offer a snapshot of gender equality in Brazil in terms of aggregate outcomes, following the WDR framework. As such, they focus on endowments-where the most progress has been made-followed by economic opportunities and agency.

\footnotetext{
${ }^{29}$ Incarcerated women are extremely vulnerable to violation of their human rights. Women prisoners may share the same space-sometimes even the same cell-with men, and female prisons are usually former male prisons that have been considered inadequate. In addition, women are comparatively more exposed to overcrowding, violence and torture; lack of medical care; and inattention to minimum standards of hygiene, as exemplified by the lack of sanitary napkins distribution (Conectas, 2015). There have been also reports of women being forced to give birth while shackled (Correio 24 horas, 2014). That practice has been officially prohibited since 2012.
} 


\section{Endowments}

The improvement in gender equality in recent decades in Brazil has been particularly marked in the dimension of endowments, as evidenced by several metrics of education and health. Women have caught up and, in several instances, surpassed men in education outcomes, and health indicators have improved substantially.

The literacy rate of youth (ages 15-24) is 98 percent for males and 99 percent for females, up from 84 percent in 1980 . Similarly, 98.7 percent of 12 -year-olds currently attend school, and even in the bottom quintile, this share is still very high, with 98.1 percent of girls and 98.3 percent of boys of this age attending school. ${ }^{30}$

School attendance rates drop rapidly between 14 and 17 years of age, however, with only 87 percent of 16-year-olds and 73 percent of 17-year-olds attending school. Nonetheless, this decline does not differ substantially between girls and boys. In fact, among older youths, females are more likely to attend school than males. One in three women 21 years of age attends school, versus only one in four of their male counterparts. With the increase in women's and girls' schooling, a gender gap in favor of girls has developed in secondary (female-to-male ratio: 1.11) and tertiary education (1.29) according to the latest data, from $2008 .^{31}$ The increase in female tertiary education is particularly notable: In 1970 the femaleto-male ratio in tertiary education was as low as 0.6.

Gender discrepancies in education increase with levels of education. While equal shares of boys and girls (92.5 percent) ages 6 to 14 were enrolled in school in 2013, the shares dropped at ages 15-17 to 60.1 percent for girls and 50.4 percent for boys. There was a dramatic drop for the next age group, 18-24 yearolds, to 18.8 percent for women, which is still meaningfully higher than the men's share, 14.0 percent. Currently, close to two-thirds of graduates from tertiary education each year are women.

Similarly, in terms of the Millennium Development Goals, Brazil has had a strong record regarding female reproductive health. Its maternal mortality rate fell from 120 per 100,000 live births in 1990 to 69 in 2013. Ninety-eight percent of births are currently attended by skilled personnel, compared to 88 percent in the mid-1990s.

However, the share of births by cesarean section in Brazil is disconcertingly high, at $\mathbf{5 7 . 7}$ percent of all births in 2012. The WHO recommends a target of 15 percent, and while the mechanisms pushing the Brazilian rate well above that it are not entirely clear, they are likely a combination of financial incentives for hospital administrators and medical staff and the preferences of pregnant women to schedule a birth in advance (Brasil 2014; Brasil 2015b). The incidence of cesareans is much higher in private hospitals (nine out of ten births) than public hospitals (Leal 2013 and Brasil 2015b). But medically unnecessary cesarean procedures may pose avoidable risks to pregnant women, and, in 2015, the Ministry of Health and the National Agency on Supplementary Health launched an initiative aimed at reducing cesarean surgeries and encouraging vaginal deliveries. ${ }^{32}$ Obstetricians are now required to provide a written explanation for each cesarean delivery. Pregnant women are given leaflets with information on vaginal and cesarean

\footnotetext{
${ }^{30}$ Authors' calculations based on the PNAD 2014.

${ }^{31}$ See World Bank 2015.

32 Resolution \#368/2015.
} 
deliveries, and health insurance companies are required to disclose obstetricians' shares of cesarean sections relative to total deliveries.

Concerning pregnancy prevention, contraceptive use is as high as $\mathbf{8 0}$ percent among married women 15-49 years of age and unmet need from family planning has fallen to 6 percent, well below the regional average of 11 percent. ${ }^{33}$ There is, however, significant variation in the type of contraception used across income quintiles. Condom use gradually increases by socio-economic level, from 10.3 percent among the poorest to 16.4 percent in the highest quintile. Female sterilization-a very invasive means of contraception-is most common among the poorest quintile (32.3 percent) and drops to 20.2 percent for the two highest quintiles. In contrast, the rate of male sterilization is only 1 percent among the poorest but 13.3 percent among the two wealthiest quintiles.

Hand-in-hand with the increase in contraceptive use, the prevalence of teenage motherhood has fallen slightly since 2001. That year, 13.6 percent of women 15-19 years of age reported having had a child. By 2014, the figure had dropped to 11.0 percent. Among those aged 15-17 in 2001, 7.3 percent reported having had a child; this share was 6.2 percent in 2014 (IBGE-SIDRA 2014).

Policies addressing poverty may also help reduce pregnancy among teenagers. In particular, there is evidence that the conditional cash transfer program Bolsa Família decreased the likelihood of teenage pregnancy, particularly for girls $16-19 .{ }^{34}$

\section{Economic Opportunities}

Closing the gender gap in education-with the share of women even surpassing that of men in higher education-has not led to equally large aggregate gains in the labor market. Rather, female labor force participation (LFP) and employment have risen only slightly over the last 20 years, from a rate of 54 percent in 1995 to 59 percent in 2014. The share of employed women moved from 50 percent to 54 percent over the same period. Graph 1 shows the very slow rise in LFP and employment by gender. While the respective rates for men declined ever so slightly and female rates increased over the last twenty years, most of this happened between 1995 and 2005. In fact, between 2005 and 2014, female LFP in Brazil did not deviate by more than 1 percentage point.

\footnotetext{
${ }^{33}$ http://mdgs.un.org/unsd/mdg/Resources/Static/Products/Progress2015/Snapshots/BRA.pdf; MDG data http://mdgs.un.org/unsd/mdg/Data.aspx.

${ }^{34}$ J.P. Azevedo and M. Favara 2012. "The Impact of Bolsa Familia on the Incidence of Teenage Pregnancies in Brazil." Background Paper for the Regional Study on Teenage Pregnancy (Azevedo et al. 2012).
} 
Graph 1. Labor Force Participation and Employment Rates, Historical by Gender

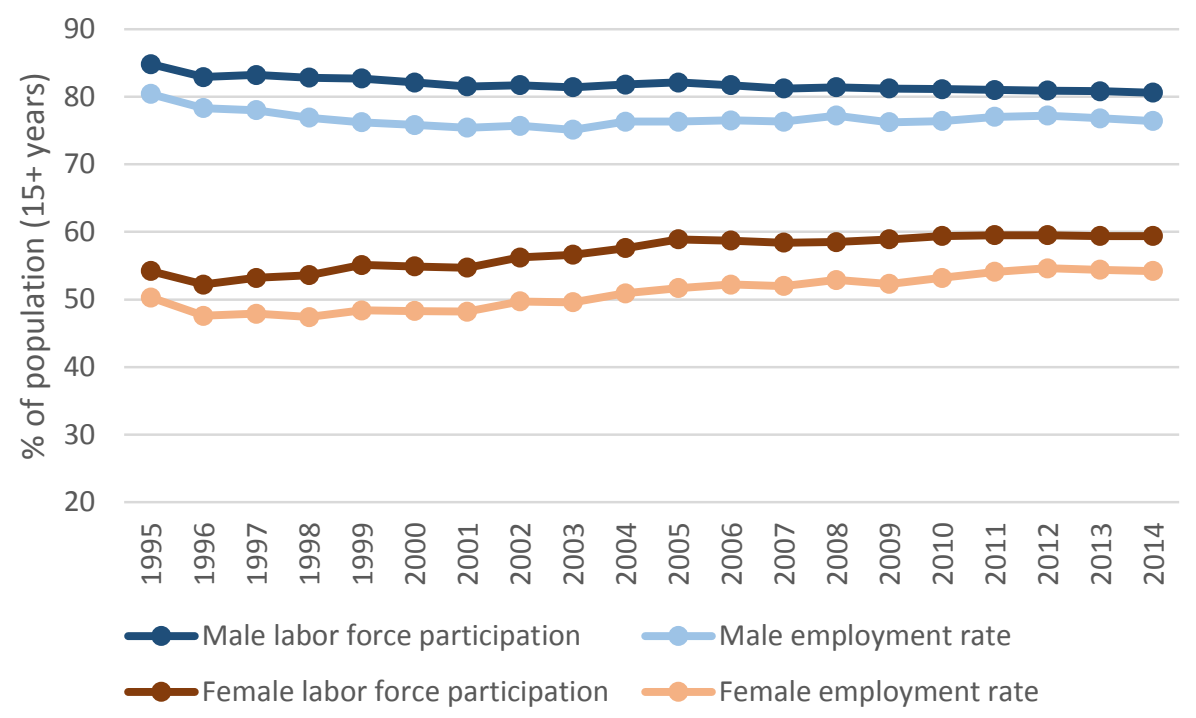

Source: World Bank 2014, World Development Indicators. Modeled ILO estimates.

For women, labor force participation increases steadily with years of education and is closest to the share of male labor force participation when comparing those with most years of education.

Figure 1 Labor force participation according to gender and years of education

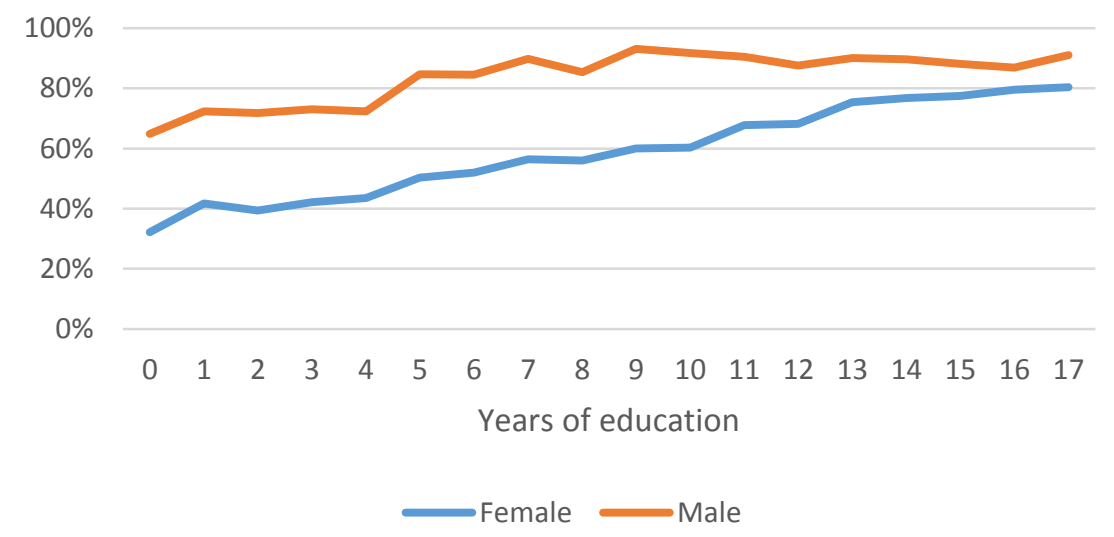

Source: Authors' calculation based on PNAD 2014-IBGE.

While labor force participation changed little in aggregate both for men or women over the past decade, large drops for some groups become notable when breaking down by age and educational level. Specifically, labor force participation among unskilled young men and women dropped significantly between 2004 and 2014. At the same time, skilled people aged 55 to 64 seem to have postponed their retirement. 
Figure 2. Changes in Labor force participation over the past decade according to gender, age and skill profile

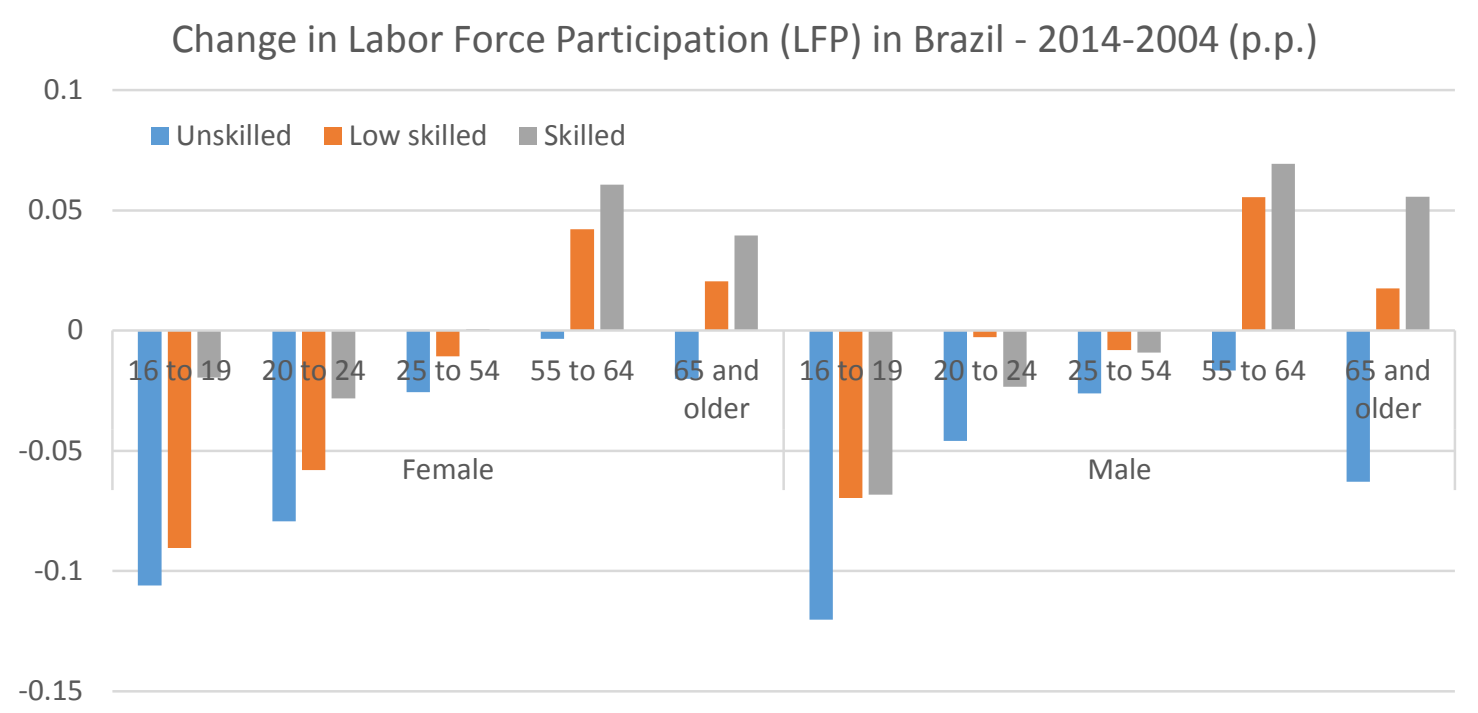

Source: Authors' calculation based on PNAD 2004 and 2014 - IBGE.

Skill definition: Unskilled - incomplete primary education Low-skilled - complete primary and incomplete secondary education Skilled - complete secondary education or more 


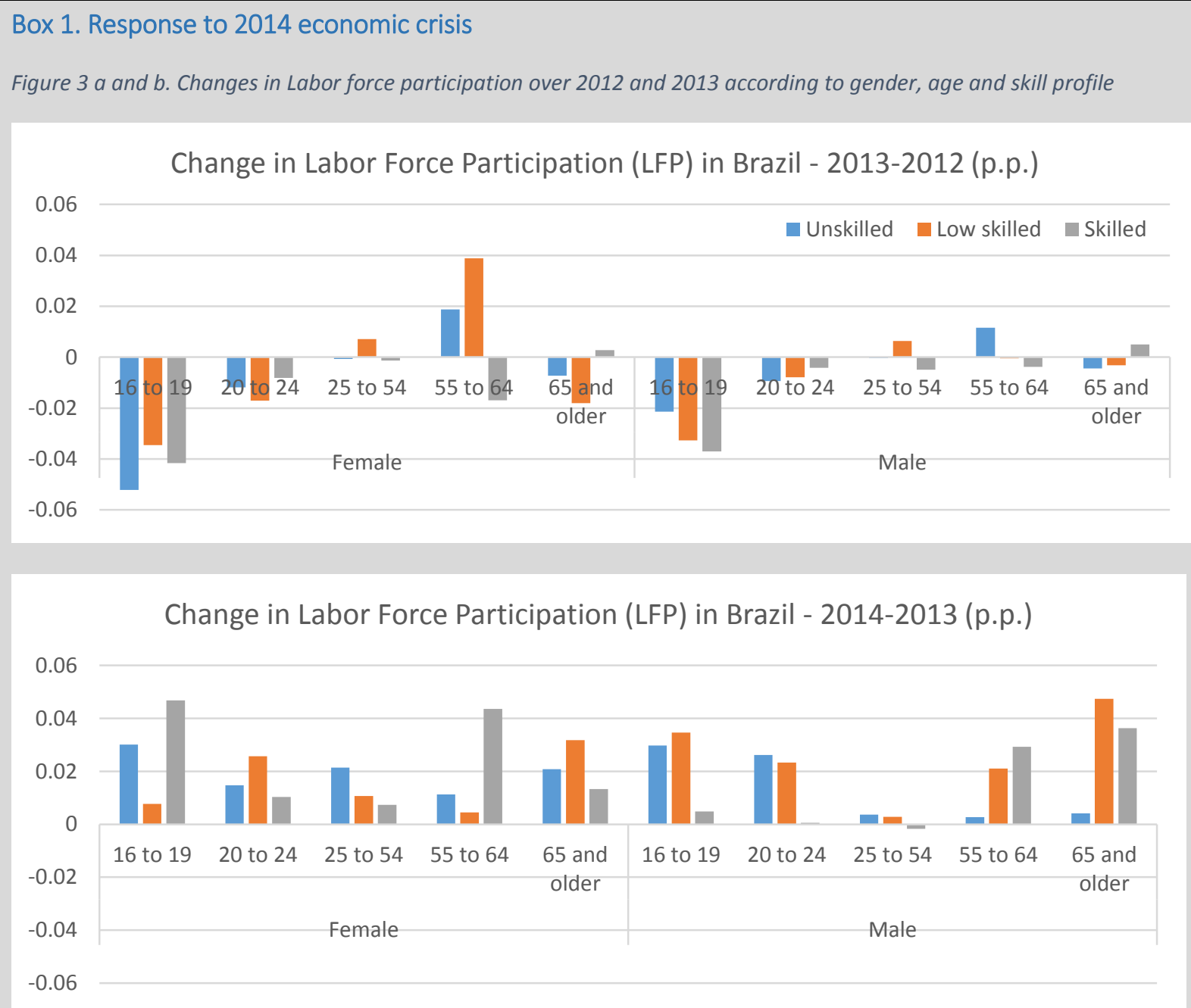

Source: Author's calculation based on PNAD 2012, 2013 and 2014 - IBGE.

Skill definition: Unskilled - incomplete primary education

Low-skilled - complete primary and incomplete secondary education

Skilled - complete secondary education or more

Figures $3 \mathrm{a}$ and $3 \mathrm{~b}$ show changes in labor force participation in one year according to gender, age, and skill profile. In 2013, the pattern seems to follow the trends of the previous decade, with young people of both sexes staying out of the labor force for longer, particularly if they have not yet finished their studies (see definition of unskilled and low-skilled above) and un- and low-skilled women between 55 and 64 postponing their retirement.

However, between 2013 and 2014 all of the groups increased their labor force participation. This trend is even more pronounced for women in general, and for young and older ( 55 and older) men. This can be interpreted as a response to the beginning of the crisis, when the main earner in the household, typically a male adult, may have seen his income drop. 
With regards to the presence of children in the household, it is interesting to note that labor force participation increases for both men and women when they have just one child-but drops continuously for females and stays constant for males with every additional child in the household.

Figure 4. Labor force participation according to number of children in the household

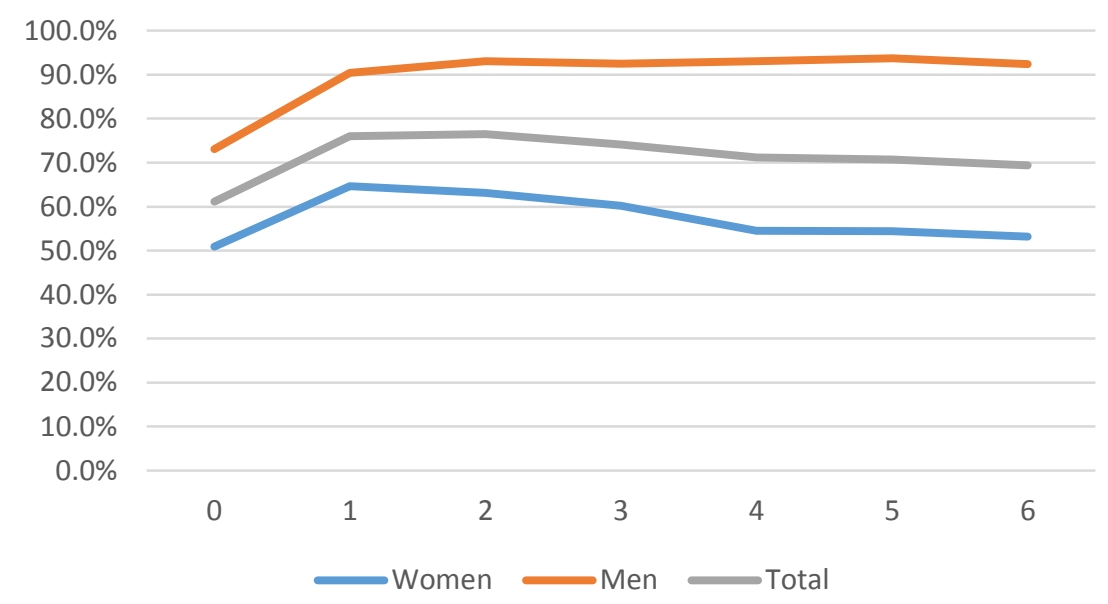

Source: Authors' calculation based on PNAD 2014 - IBGE.

Labor force participation among women is particularly high in single-parent households with children, followed by single-parent households with the presence of at least a second adult woman. When there are two parents and children, women tend to stay more at home, even if there is another female adult present in the household. These results do not change when there is a teenage girl in the household. 


\section{Women LFP according to HH type}

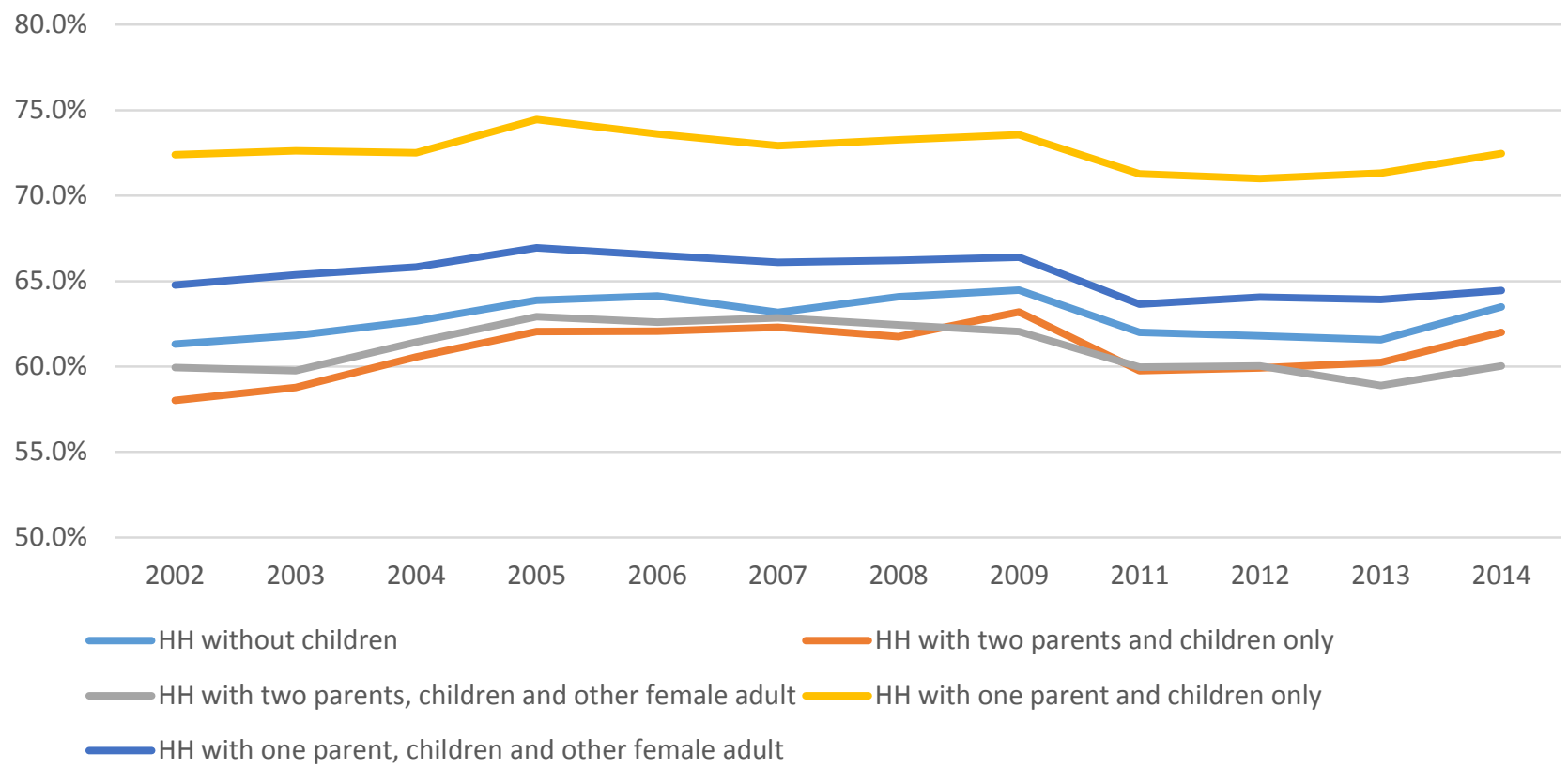

Source: Authors' calculation based on PNAD-IBGE.

Labor force participation among women is higher in the top quintiles of the income distribution, regardless of the household composition. Women in households with both parents and another female adult tend to participate less in the labor market than those in households with both parents and children. Among women in the poorest two quintiles, LFP does not change much whether they have children or not in the household. In single-parent households, which are typically led by women (Box 2), LFP is higher when there is no other adult female in the household, probably indicating the necessity of the source of income. 


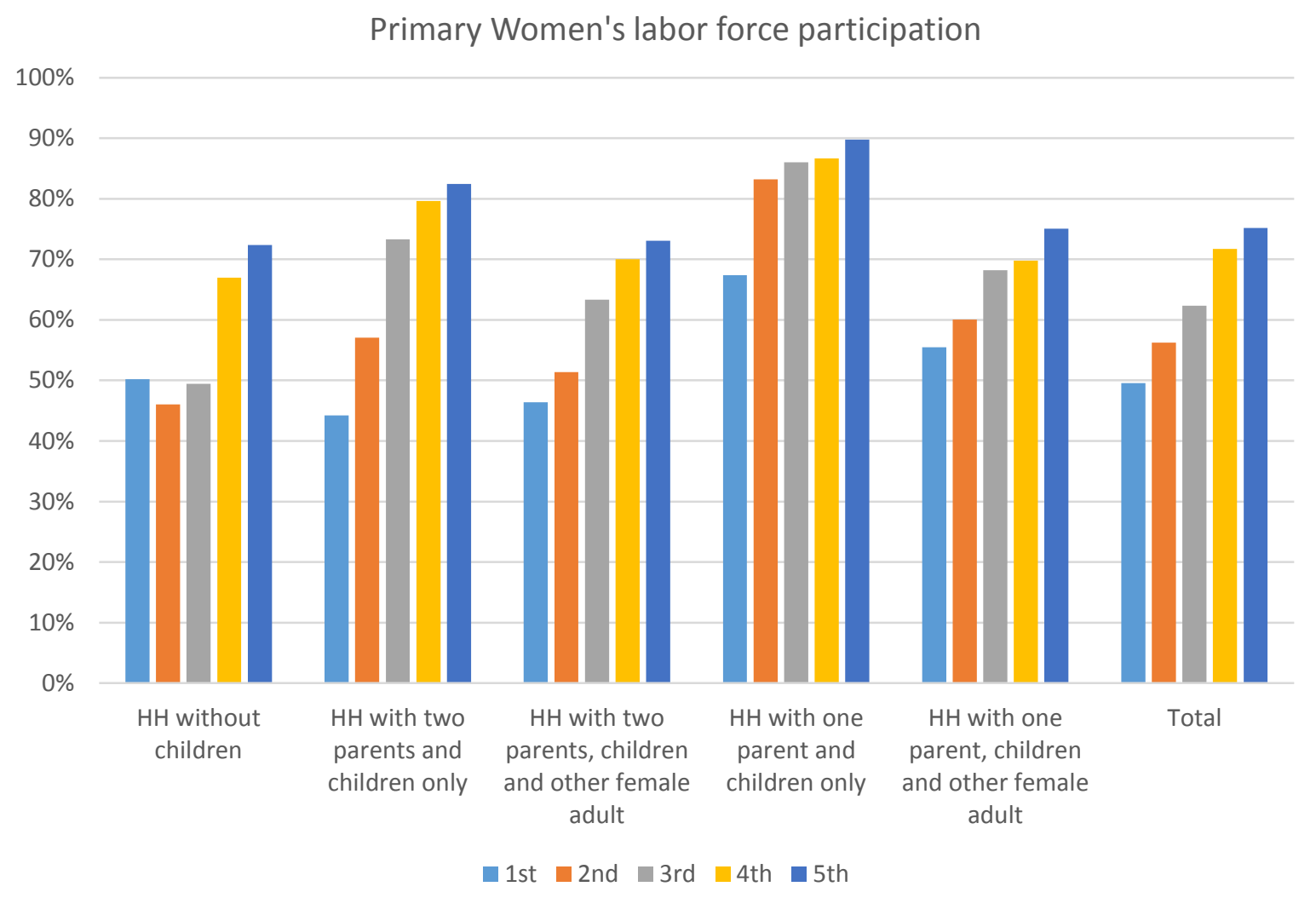

Source: Authors' calculation based on PNAD 2014-IBGE.

35 'Primary' being the 'main' woman in the household, either the head of the household or the spouse of the household head. 
Box 2. Household composition across the income distribution

Figure 7. Household composition according to income quintile in 2014

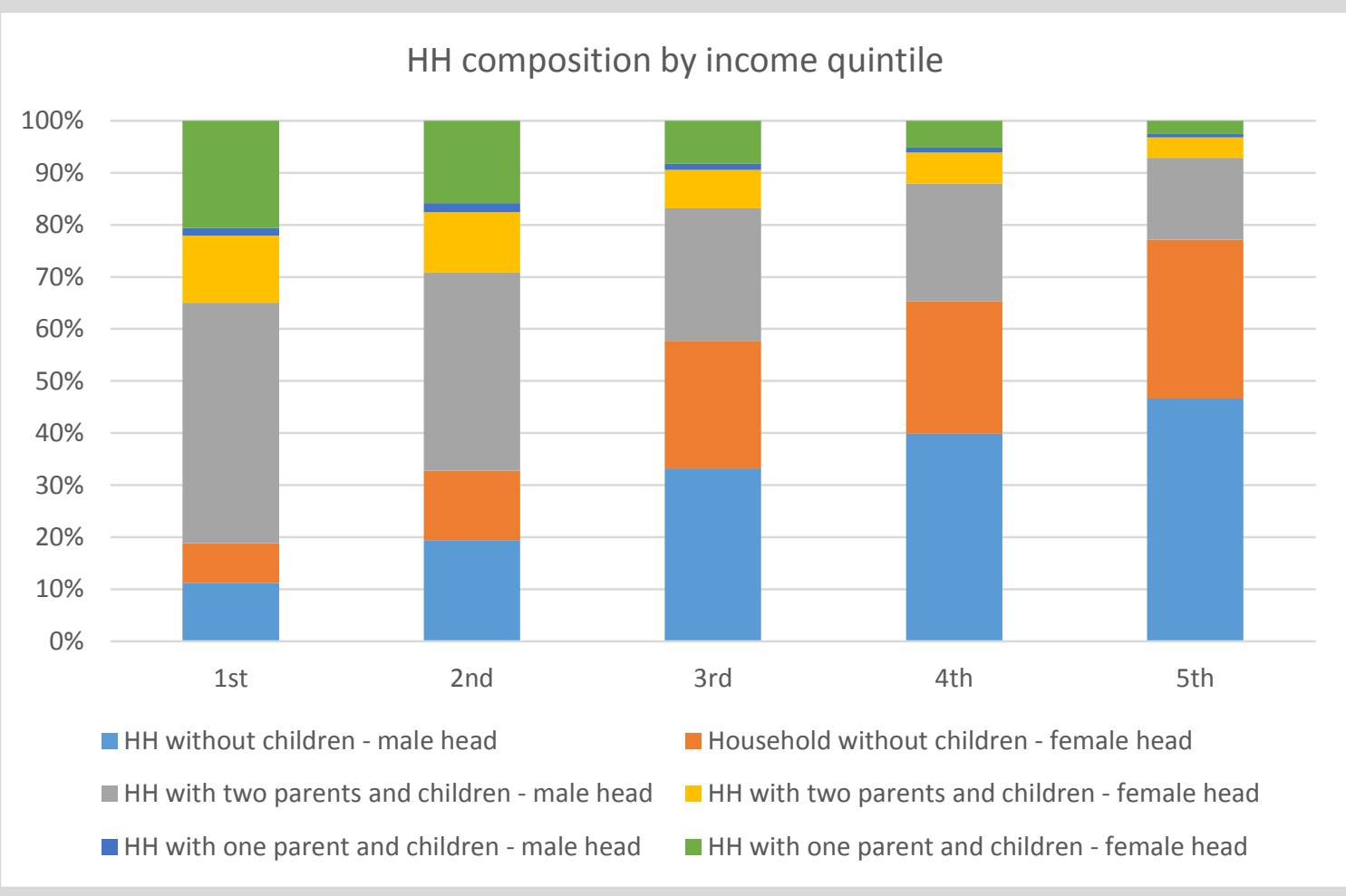

Source: Author's calculation based on PNAD 2014-IBGE.

Household composition varies clearly when comparing different income quintiles. While in the bottom quintiles households without children are underrepresented (independent of the sex of the household head), single-headed households are almost inexistent in the top quintile, representing only 3 percent. Single-parent households are almost always led by women. This group represents 21 percent of the households in the poorest quintile, while only 3 and 5 percent respectively in the top two. Men are typically the head of households with children and two parents. The share of those households led by women is 22 percent.

Though they have lower LFP rates, women also face higher levels of unemployment relative to men, particularly among younger cohorts. In 2013, the average unemployment rate was 6.3 percent (for the population aged 15 and higher). For women it was 8.2 percent versus 4.8 percent for men. This gap widens significantly in the younger population, with 17.1 percent of women ages 18-24 being unemployed compared to 10.8 percent of men in the same age range (IBGE 2015).

Labor force participation and employment figures mask occupational segregation, which shows up not only in the differences in gender representation in different sectors, but in vocational training and entrepreneurship. In Brazil, female employment is still concentrated in sectors related to traditionally female roles: accommodation and food, education, health, social services, and domestic services. 
Together, these sectors account for approximately 45 percent of working females, while about 48 percent of employed men were engaged in the agricultural, industrial, and construction sectors (BRASIL 2014).

Vocational training courses reflect similar patterns of gender segregation. Men are concentrated in courses on the military (91.2 percent of students are men), industrial processes (80.6 percent), information and communication (62.3 percent), natural resources (60.7 percent), and infrastructure (59.7 percent), while women comprise the majority of those enrolled in education ( 83.4 percent), health (82 percent), and tourism and hospitality (73 percent) (Brazil, 2014). This segregation has severe implications for labor market outcomes and earnings, as the traditionally male sectors tend to be growth sectors while those in which women are concentrated have weaker potential.

The rate of female entrepreneurship in Brazil is close to the regional average, with 15 percent of working-age women about to start or currently running a new business. This is also very close to the male rate of 16 percent. ${ }^{36}$ But the share of female entrepreneurs operating single-person businesses in Brazil is substantially higher than that of male entrepreneurs -71 percent versus 55 percent. This suggests a willingness among women to start business but also the existence of barriers-actual or perceived-for the growth and sustainability of female-owned businesses (Kelley et al. 2013).

Gender stereotypes are also found in the resources available to entrepreneurs, heightening the barriers that women face in working in higher-growth sectors or using cutting-edge technology. ${ }^{37}$ Business training offered to women is often gender-biased, particularly in rural areas, where women are channeled into courses on traditional roles such as cooking and sewing. Female-owned businesses are concentrated in the micro and small end of the spectrum. They grow more slowly, use less labor and physical capital, and are focused in the commerce, services, and manufacturing sectors, which tend to be less profitable overall.

The distinction between necessity- and opportunity-driven entrepreneurship is also important, and cuts across gender lines. Entrepreneurship in Brazil follows a pattern observed in many developing countries, where barriers to entering the employment labor market-including gender wage differentials, lack of flexibility, and caretaking responsibilities-tend to push women to become entrepreneurs (Pines et al. 2010). This leads them to set up small businesses out of necessity, because they have no other options, rather than in response to a business opportunity. ${ }^{38,39}$

\footnotetext{
${ }^{36}$ See Kelley et al. 2013, which considers the Total Early-Stage Entrepreneurial Activity Rate or TEA. The TEA includes those in the process of starting a business (nascent entrepreneurs) and those running a new business beyond the nascent stage (three months) but before the established business phase (three and a half years).

${ }^{37}$ World Bank 2009.

38 "Entrepreneurs out of necessity" are defined by Global Entrepreneurship Monitor (GEM) as those who, when asked in the survey "Are you involved in this start-up/firm to take advantage of a business opportunity or because you have no better choices for work?" opt for the latter answer.

39 See GTZ, World Bank, and IDB 2010 for a discussion on female entrepreneurship in Latin America and the Caribbean and a case study on Brazil.
} 
Graph 2. Shares of Businesses Motivated by Necessity and by Opportunity
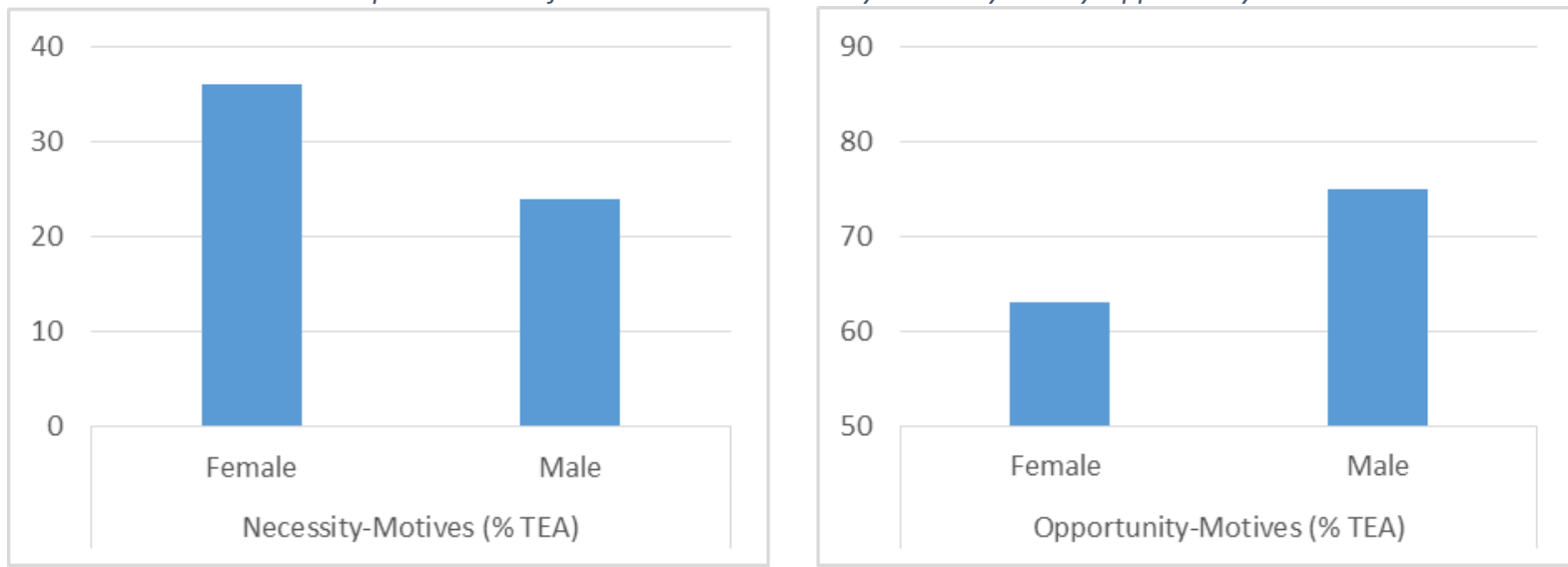

Source: Global Entrepreneurship monitor: 2012 Women's Report.

Note: TEA refers to the "Total Entrepreneurial Activity Rate" (see footnote 41).

The sexual division of labor is also reflected in differences between men and women in the number of hours worked in paid work and domestic tasks. In Brazil, women tend to spend an average of 22.7 hours a week on domestic work, or four times as much as that reported by men, 5.5 hours. Not only does this division drive down women's earnings by limiting the time they spend on paid activities, but it may also lead women to seek employment that has flexible or shorter hours. This work is more likely to be found in the informal sector or in low-growth entrepreneurship.

Brazilian women work for more hours than do men, when both paid and domestic work are taken into account. Women spend an average of 41.5 hours per week at work, compared to the 37.3 hours spent by men. The difference between sexes increases substantially when considering employed persons: women work about 55.4 hours a week, or eight more hours than men. This pattern is not unique to Brazil and is known as the "double burden" of employed women, who manage both an employment shift and a domestic shift of work. It is closely tied to the limitations and lack of progress in economic opportunities that Brazilian women face.

Table 1. Average Number of Hours Worked per Week, by Sex (ages 16 and above)

\begin{tabular}{|l|c|c|c|c|}
\hline & \multicolumn{2}{|c|}{ Women } & \multicolumn{2}{c|}{ Men } \\
\hline Type of work & All & Employed & All & Employed \\
\hline Domestic work time & 22.7 & 19.2 & 5.5 & 5.2 \\
\hline Paid work time & 18.8 & 36.2 & 31.8 & 42.3 \\
\hline Total & $\mathbf{4 1 . 5}$ & $\mathbf{5 5 . 4}$ & $\mathbf{3 7 . 3}$ & $\mathbf{4 7 . 5}$ \\
\hline
\end{tabular}

Source: Authors' calculations from PNAD 2014.

Constraints to women's employment and earnings translate into less progress against poverty. In Brazil, 15 percent of the overall reduction in poverty in 2004-2014 (measured as the percentage of the population living on less than US\$4 per day in 2005 PPP) was fueled by higher labor incomes from female 
workers. In the same period, women's increased labor income contributed 11.7 percent to the overall reduction of extreme poverty ( $\$ 2.50$ per day). ${ }^{40}$ Increasing female economic opportunities and earnings thus has the potential to accelerate the decline in household poverty in Brazil.

The lack of economic opportunities for women also likely contributes to the growing phenomenon in Brazil of "nem-nems," or youths and young adults who are neither studying nor working. ${ }^{41}$ Women are more likely to be in this category than are men, with the share of female nem-nems jumping substantially at the end of secondary school. At 16, 10 percent of girls have this level of disengagement, and at 17 the share rises to 16 percent. But from ages 18 to 35, a roughly constant share of about 35 percent of women are neither in school nor working. In contrast, disengagement peaks at age 18 for men, but gradually decreases thereafter, as the vast majority switch into work. By 25 years of age, only 10 percent of men fit into the nem-nem category (PNAD 2014). This gender gap has to be seen in the context of women's lower returns for education and lower overall wages relative to men in Brazil.

Box 3: "Nem-nems" in Brazil - A gendered perspective on economic and educational disengagement among youth, evidence from qualitative research by Machado and Müller, forthcoming.

The nem-nem phenomenon in Brazil is a predominantly female problem: Young women account for two-thirds of the nem-nem population. The single most important factor driving women in that direction is marriage before age 18 , compounded by teenage pregnancy. Girls and boys may have different perceptions about their roles in society and about how government addresses their concerns and responds to their personal needs and interests. Furthermore, gendered social norms about women's and men's roles in families, communities, and societies can shape girls' and boys' aspirations and educational attainment.

Preliminary findings emerging from a qualitative study on nem-nems in Brazil (with data collected in Recife, Pernambuco) are that youth (both boys and girls) face an unsurmountable gap between themselves and "desired outcomes." Boys and girls lack agency (the ability to make effective choices and to transform those choices into desired outcomes, as defined in WDR 2012) and face external barriers beyond their control which makes it difficult to achieve desired outcomes. According to Perova and Vakis (2013), agency has two dimensions: An internal dimension (the internal motivation to make a decision and the predisposition to act to achieve certain objectives) and an action dimension (the implementation of decisions and taking steps to surpass external barriers). Based on this theoretical framework, three types of individuals can be identified in the data:

1. Those who express the internal motivation to engage in school or work, who take action based on that motivation, but who face multiple external barriers that block the desired outcomes;

2. Those who express the internal motivation to engage in school or work, but do not take action (due to multiple reasons) to transform the motivation into their desired outcome;

3. Those who express no internal motivation to engage in school or work and thus do not take any action either.

Interestingly, boys seem more concerned overall about not working or studying and thus tend to constantly look for even minimal tasks to perform (bicos), with eventual moments of success. They also seem less socially isolated.

\footnotetext{
${ }^{40}$ World Bank LAC Equity Lab calculations based on CEDLAS and World Bank data.

41 "Nem-nems" can be translated from Portuguese as "neither-nors."
} 
Contrary to that, girls tend to be more accepting of roles as mothers and depending on either a parent or a partner. They do not take action to change their situation and seem to conform much more than boys with not being an active income earner. Early marriage and teenage motherhood seem to be a very important driver behind the female nem-nems. These differences are strongly linked to gendered social norms and the way those shape aspirations and life plans.

Having a baby aged less than three is the most significant factor in determining that a young woman would be a nem-nem, a recent study found. Monteiro (2013) concluded that having such a baby increases the probability of her staying out of the labor market and not studying by over 23 percentage points. However, as the child grows older, the mother tends to return to the labor market. After controlling for having a child below three years in the household, being a mother before the age of 18 decreases the probability of the mother being a nem-nem. This indicates that teenage pregnancy is a determinant for women to not be in school or working, but not necessarily for staying out of the labor force permanently. On the other hand, the author does not explore the current household composition. An increase in labor force participation could also be associated with single parent status.

\section{Agency}

The WDR 2012 defines agency as "an individual's (or group's) ability to make effective choices and to transform those choices into desired actions and outcomes." We consider three dimensions of female agency-political representation, teenage pregnancy, and gender-based violence.

Although a person of any gender may become a victim of domestic violence, women are more likely than men in all countries of the world to suffer violence within the private sphere, often from an intimate partner or family member. Violence against women is common and a widespread social problem. Recent research on victimization in Brazil (Fundação Perseu Abramo 2010) shows that 40 percent of women stated that they had been subjected to violence by a man at least once in their lives. ${ }^{42}$ Husbands and ex-husbands, boyfriends and ex-boyfriends, were identified as the main parties engaging in abusive behavior, confirming the findings of previous research on the topic (WHO 2005). ${ }^{43}$

While prevalence data of high quality, costly to collect, are not available on a recurrent basis, it seems evident that domestic violence is not declining at a fast pace. Taking deadly violence against women as a proxy leads to this conclusion, which seems at odds with the widespread efforts to address this issue. But implementation of the Maria da Penha Law has been slow, in view of four major factors:

\footnotetext{
42 Physical, sexual, psychological violence are included, as well as threats, harassment, and control of behavior.

${ }^{43}$ The WHO multi-country study on violence against women included Brazil. The research found that in São Paulo 27 percent have experienced physical violence by their intimate partner at least once in their lives; in Pernambuco this share was 34 percent. Ten percent of women reported having experienced sexual violence in São Paulo compared to 14 percent in Pernambuco. Combining the data for physical and sexual violence, 29 percent of ever-partnered women in São Paulo and 37 percent in Pernambuco had experienced physical or sexual violence by a partner.
} 
a) Responsibility for implementation lies with states and municipalities that often fail to sufficiently expand the service network due to lack of financial, political, and technical capacity.

b) There is often poor communication between services, leading to efficiency gaps in referring victims between services.

c) Policy and legal frameworks are progressive in many aspects but regressive in others, notably in their tendency to stress punishing perpetrators rather than preventing the crimes from happening in the first place.

d) Domestic violence is profoundly intertwined with social norms, which do not change at fast pace.

Brazilian men face higher homicide rates than women, but women are more likely to be a victim of violence perpetrated by a person they know. Among men, 1.8 percent of respondents to a survey on violence in Brazil report having been a target of violence by a known person, in contrast to 3.1 percent of women. ${ }^{44}$ The most common perpetrator for male victims is a friend or co-worker. In contrast, partners are the most common aggressors for female victims aged 18-29, followed by ex-partners. Moreover, of the women reporting violence by a known person, 12 percent say they suffer an aggression on a weekly basis, in contrast to 4.6 percent of their male counterparts. On the other hand, men are more likely to experience violence by an unknown perpetrator -3.7 percent of men and 2.7 percent of women (Waiselfisz 2015).

Public tolerance of domestic violence and the perception that victims are to blame are very common in Brazil, according to a survey that IPEA conducted in 2014. More than 40 percent of interviewees fully agreed with the following statement: "A woman who is attacked by a partner and continues with him enjoys being beaten." An additional 22.4 percent agreed partially with that statement. Furthermore, 26 percent of interviewees agreed (13.2 percent totally and 12.8 percent partially) with the following statement: "Women who wear clothes showing their body deserve to be attacked." 45

Social and institutional acceptance of gender-based violence is even more disturbing when found within the public network set up to protect female victims of violence. A survey carried out in the state of Rio de Janeiro in 2013, for example, asked health and public safety workers as well as employees in CEAMs about the following claim: "If women were well-behaved, there would be fewer rapes." Forty percent of respondents in the health sector, along with 34 percent in public safety and 24 percent in the CEAMs, agreed or strongly agreed with the statement. Just as disconcerting, the respective shares agreeing with

\footnotetext{
${ }^{44}$ FLASCO 2015. This information is based on data from the Pesquisa Nacional de Saúde, a household survey carried out by the Ministry of Health and IBGE. Respondents aged 18 or older were asked, "Over the last 12 months, were you a victim of violence or aggression by a known person (such as a father, mother, child, spouse, partner, boy/girlfriend, friend, or neighbor)?"

${ }^{45}$ http://www.ipea.gov.br/portal/index.php?option=com_content\&view=article\&id=21971
} 
"It is natural for men to be explosive" were 23 percent, 36 percent, and 26 percent for each of those respondent groups (CFEMEA 2014). ${ }^{46}$

Women's political participation and representation are still very weak in Brazil and have changed little over the last decades. While Brazil is one of the few countries in the Latin America and the Caribbean region that has had a female president, Dilma Rousseff, only six out of 39 ministers in her second government were female, and they were generally appointed to "softer" areas such as human rights, racial equality, and policies for women. Even more discouraging, none of the new ministers whom current interim president Michel Temer selected for his government in May 2016 are female. ${ }^{47}$

A recent change to the Brazilian electoral code set out a requirement that $\mathbf{3 0}$ percent of each political party's candidates must be women, and that at least 5 percent of financial resources must be allocated to promoting female political participation and meeting this quota. As a result, the number of female candidates in the last general election, in 2014, increased by 47 percent over 2010-from 5,056 to 7,437 (TSE 2014).

Despite the higher number of women candidates, the election results did not significantly change the gender make-up of law-making bodies. In 2010, 45 women were elected to the Chamber of Deputies; in 2014,51 female candidates secured seats. The numbers represent respectively 8.8 and 9.9 percent of the chamber's 513 deputies. For the Federal Senate, which renewed one third of its 81 seats in 2014, five female senators were elected, joining another six previously chosen. Women now occupy 13.6 percent of all Senate seats. These figures are significantly below the Latin America and Caribbean average of 26 percent of politicians in parliament being female. The Inter-Parliamentary Union ranks Brazil $113^{\text {th }}$ in the world in its "List of Women in National Parliaments." 48

At the state level, leadership functions are equally male-dominated, with only one female governor elected in $\mathbf{2 0 1 4}$ for the $\mathbf{2 7}$ posts available. In state parliaments, the number of women elected actually decreased between 2010 and 2014: 120 female candidates won seats in 2014, compared to 141 in the previous cycle. Finally, at the local level, only 11.8 percent of elected mayors and 13.3 percent of city councilors are female (CEPAL Gender Observatory, data for 2014).

\footnotetext{
${ }^{46}$ The survey results are not representative of the Health Secretariat, Public Safety Secretariat, or the CEAMs, but employees at several levels of each institution were surveyed, including those at urgent care centers and specialized health centers for the care of female victims of violence (Health); and police stations and DEAMs (Public Safety).

${ }^{47}$ http://www2.planalto.gov.br/presidencia/ministros

${ }^{48}$ See: http://www.ipu.org/wmn-e/classif.htm
} 


\section{A Closer Look by Race and Geography: Mixed Results}

In Brazil-the world's fifth largest country by both population size and land mass-ethnic and racial identities as well as geographic location yield unique outcomes at their intersection with gender. Aggregate achievements in gender equality often overshadow an important issue for gender in Brazil: inequalities between women based on race, ethnicity, and region where they live.

A closer look at gender equality by sub-group of women reveals not only that certain gains do not reach all groups of women equally, but also highlights how policies on gender can be more effective if they take race or geography into account. Efforts to increase female labor force participation and employment, for example, are likely to get more traction if they go beyond trying to close the average difference in wages between men and women, to also address additional wage penalties faced by AfroBrazilian women relative to men and to white women.

In aggregate terms, women in Brazil have made significant progress in education, but disparities remain across race and regions. Women have surpassed men in several metrics of education. Among those 25 and older, women have an average of 8.4 years of education, relative to 8.0 years for men. But stark disparities quickly emerge when disaggregating by race, with white women reporting over a year more of education than women who self-identify as black or parda (Afro-Brazilian): ${ }^{49} 9.1$ versus 7.7 years. Regional differences also arise, as women in the Southeast and the Center-West report 8.8 years of schooling, compared to 7.5 for those in the Northeast. The average years of schooling for women 25 years of age and older is lowest in the state of Alagoas (North) at 6.8 years, followed by Piauí (Northeast) with 7.1 years. In contrast, the average for women in Brasília is 10.3 years (PNAD 2014).

49 The Brazilian Institute of Geography and Statistics (IBGE-Instituto Brasileiro de Geografia e Estatística) distinguishes five racial and ethnic categories in its census and household surveys, according to self-declaration: preto (generally understood as dark-skinned Afro-descendants), pardo (generally light-skinned Afro-descendants or those of mixed race), indígena (indigenous), amarelo (Asian-descendants), and branco (white). Pretos and pardos comprise the broader group of Afro-descendants, who, in Brazil, are also collectively referred to as "negros." In this note, we use the term "Afro-Brazilian" when referring to both preto and pardo demographics together, and black when referring to self-identification as preto in IBGE surveys. 
Average years of education

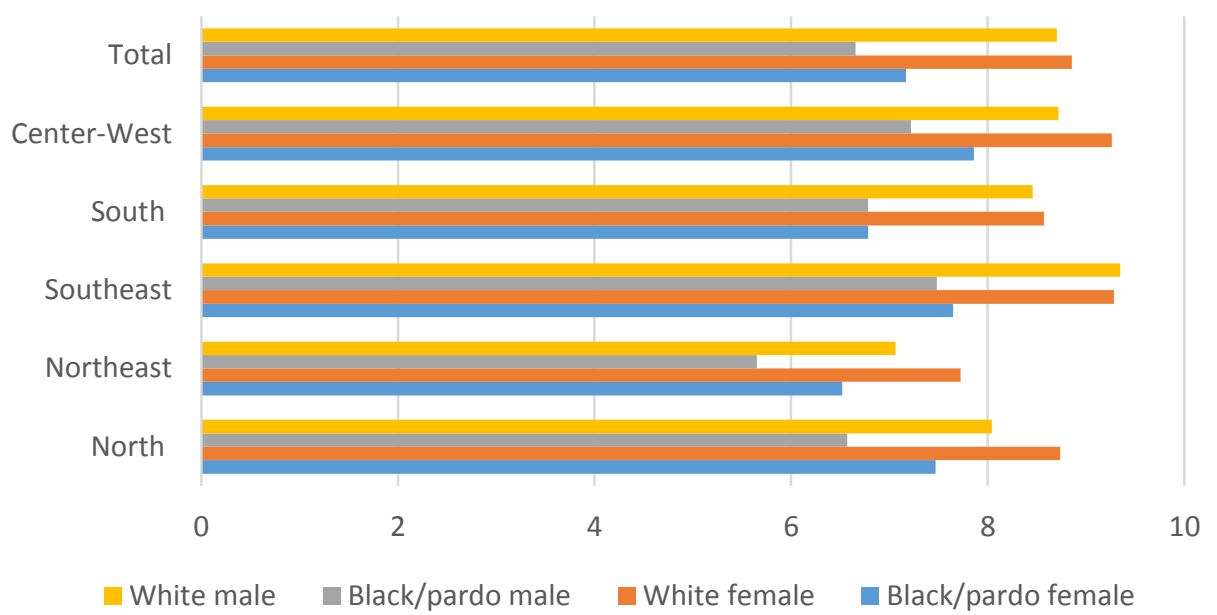

Source: Authors' calculation based on PNAD 2014-IBGE.

Regional and state disparities among women are relevant not only for their implications for inequality but also for finding answers on how to address them, as education is a shared responsibility between the federal, state, and municipal levels. While literacy rates gravitate around 98 percent for both sexes in the urban populations of São Paulo, Rio de Janeiro, Distrito Federal, and Rio Grande do Sul, rural populations have much lower rates across the country. The lowest rate is 57.1 percent for men in Alagoas (IBGE 2015). Tackling these racial and geographic inequalities is critical for reaching gender equality, as it is certainly harder-and in some instances mathematically impossible-to raise female aggregates substantially if a large sub-group of women lags behind.

In this section, we revisit outcomes in the three dimensions of gender equality-endowments, economic opportunities, and agency-and explore inequalities among Brazilian women. This approach reveals that though Brazil has made the most progress on endowments, particularly in education and health, Afro-Brazilian women and women living in the northern part of the country still fall far behind their white or southern counterparts. And in areas of economic opportunities and agency, where aggregate outcomes for all women have a lot of room for improvement, these same groups of women are systematically disadvantaged. They are segregated into more precarious employment sectors, face lower returns to education, and are more likely to be victims of violence.

\section{Endowments}

Adult literacy rates and years of education largely reflect policies of previous decades, but figures on current school attendance in Brazil retain similar patterns-substantial female gains in aggregate but persistent inequalities by race and geographic area. Nearly all children aged 7-12 attend school in Brazil, and while participation rates decline rapidly at higher ages, there is little difference between the rates for high school-aged boys and girls. There are, however, important differences between regions. Girls aged 
13-16 in the North, Northeast, and Center-West are less likely to attend school than girls of that age group in the Southeast and South.

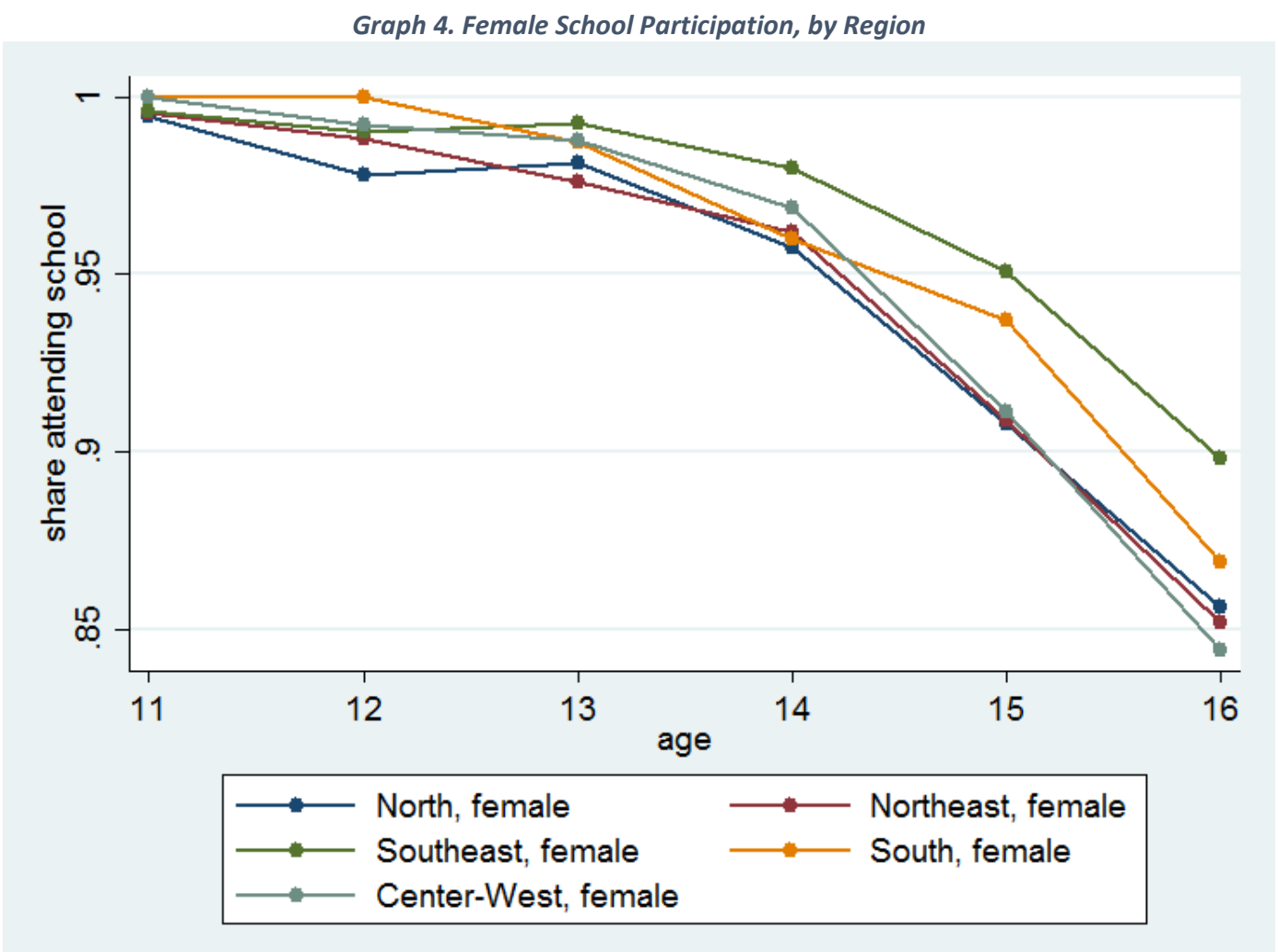

Source: Authors' calculations from PNAD 2014.

Note: The relevant question captures whether an individual is "currently attending school." 


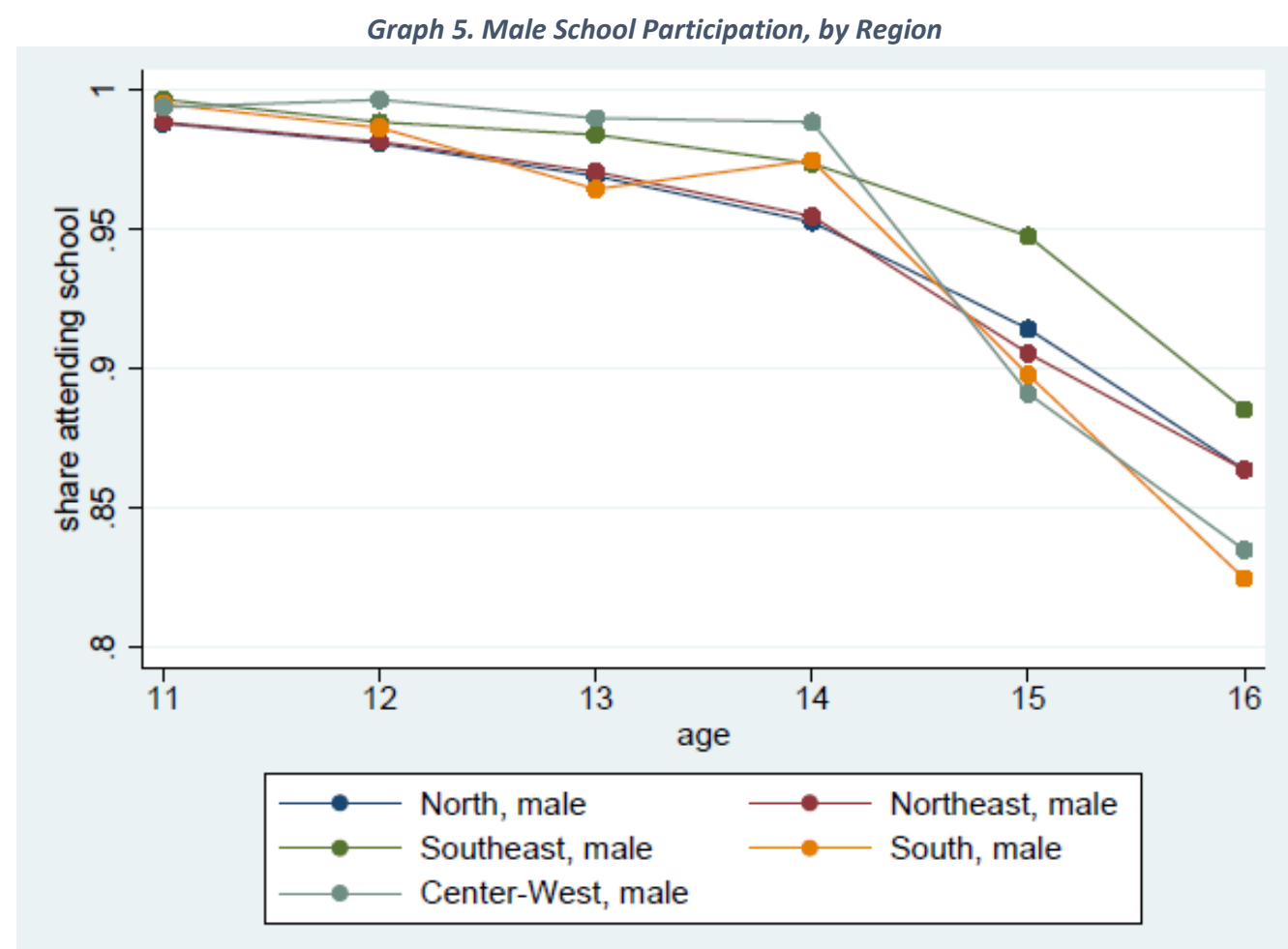

Source: Authors' calculations from PNAD 2014.

Note: The relevant question captures whether an individual is "currently attending school."

From age 19 onward, girls are on average more likely to attend school than boys, but this pattern is not even across races. Rather, while young white women over age 19 are more likely to attend school than their male counterparts, the contrast in attendance rates between genders is not as clear among AfroBrazilians. As such, the high aggregate enrollment rate of all young women relative to all men is primarily driven by the high enrollment rate of white women compared to other groups. 
Graph 6. Older Youth School Participation, by Gender and Race

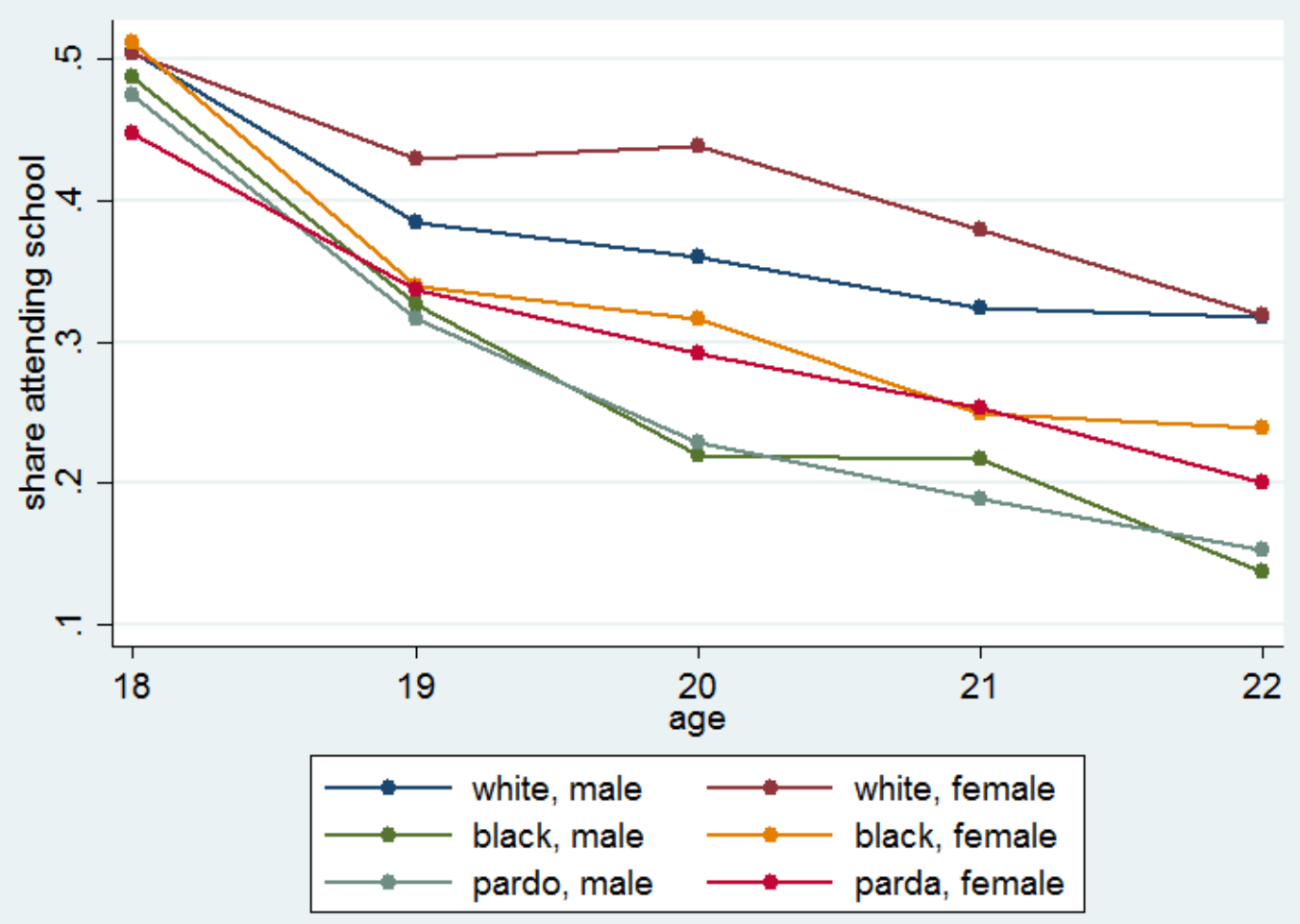

Source: Authors' calculations from PNAD 2014.

Note: The relevant question captures whether an individual is "currently attending school."

Afro-Brazilians have not only suffered disadvantage in terms of education outcomes, but also in content of schooling, which until very recently included next to nothing on issues of Black history and culture. The establishment of curriculum guidelines on the history of Africa and Afro-Brazilian culture, provided for in Law 10,639/2003, aimed to address the issue.

Furthermore, Afro-Brazilians still face challenges in access to higher education. Previous governments implemented PROUNI (the "University for All" Program), which established affirmative action programs for students from public schools, Afro-Brazilians, and indigenous peoples. Furthermore, most federal and state universities have adopted quotas for Afro-Brazilians and indigenous women and men. Nevertheless, persistent inequalities remain: in 2013, the enrollment rates in universities for blacks/pardos were less than half (10.8 percent) of the enrollment rate for whites (23.8 percent). The reverse gender gap in access to higher education holds also for the Afro-Brazilian population, but with only 8.9 percent of black men and 12.8 percent of black women enrolled (IBGE 2015).

The incidence of child labor has declined in Brazil but is more common among boys than girls, with important regional differences. Child labor is not only an inherent challenge to children's rights, but it also undermines endowments, potentially hindering children's educational attainment and learning and health. In Brazil, 636,000 boys and 276,000 girls aged 5-14 are reported as working, comprising 7.7 percent 
and 3.5 percent of their population, respectively. In Acre and Pará (both in the North), as many as 15 percent of boys in this age group work, while the state with the highest incidence of female child labor is Piauí (Northeast), where 11 percent of girls 5-14 work.

Graph 7. Incidence of Child Labor (ages 5-14), by Gender and Region

\section{Incidence of child labor}

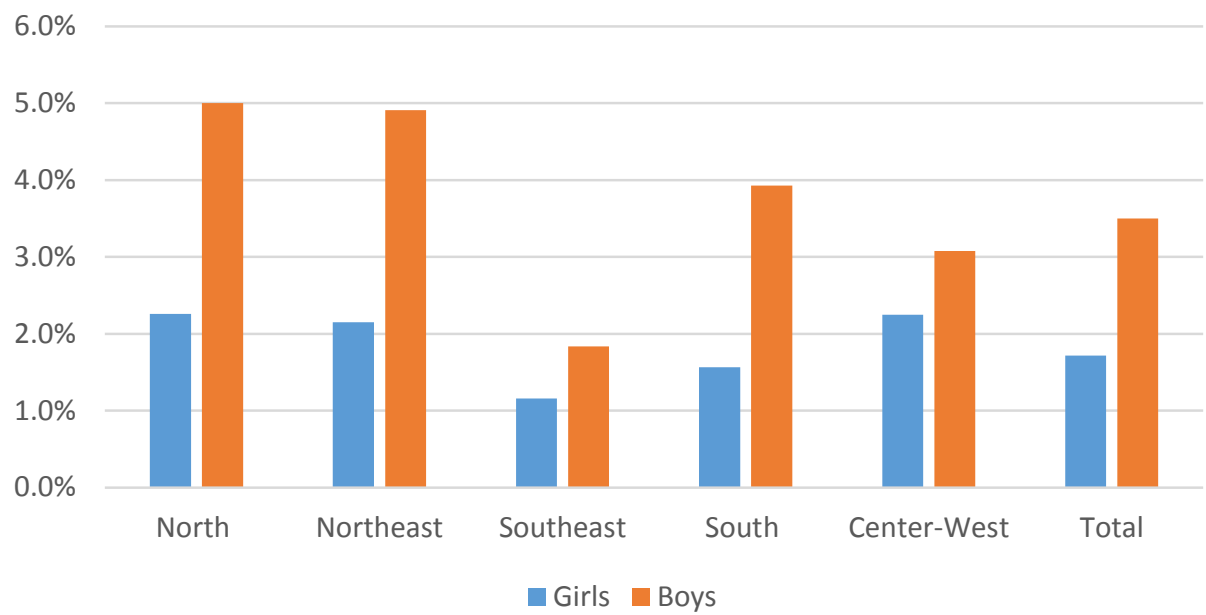

Source: Authors' calculations from PNAD 2014.

Disengagement of female youth and young adults also varies by geographic area, particularly across urban/rural divides. Young women are more likely to be disengaged from both school and work than are men, with one in three women ages 18-35 neither working nor attending school. The prevalence of this phenomenon, however, is much higher in rural areas, where as much as half of women in this age range do not work or attend school. 
Figure 8. Distribution according to School Attendance and Occupational Status - Urban Women

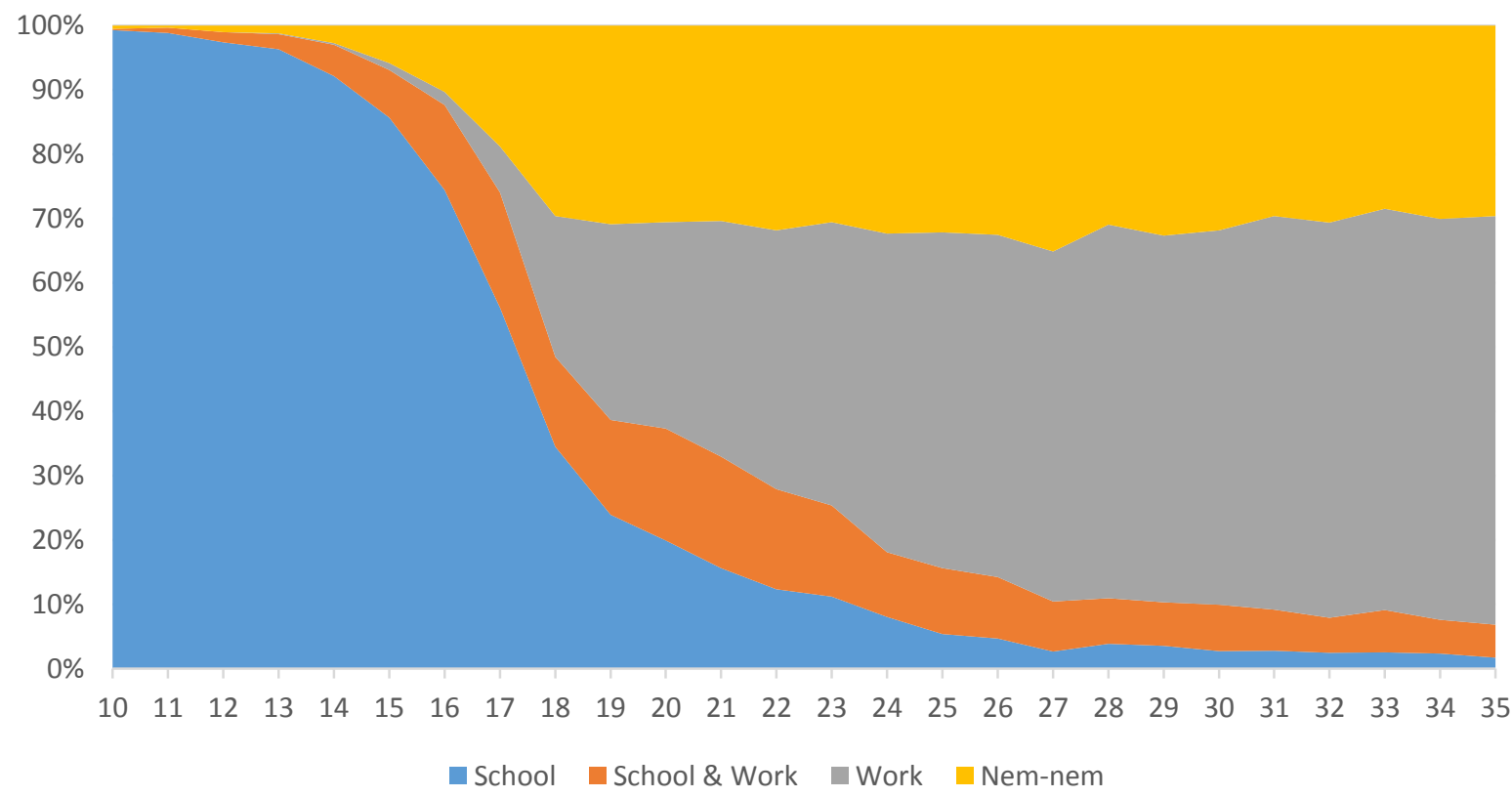

Source: Authors' calculation based on PNAD 2014 - IBGE.

Figure 9. Distribution according to School Attendance and Occupational Status - Rural Women

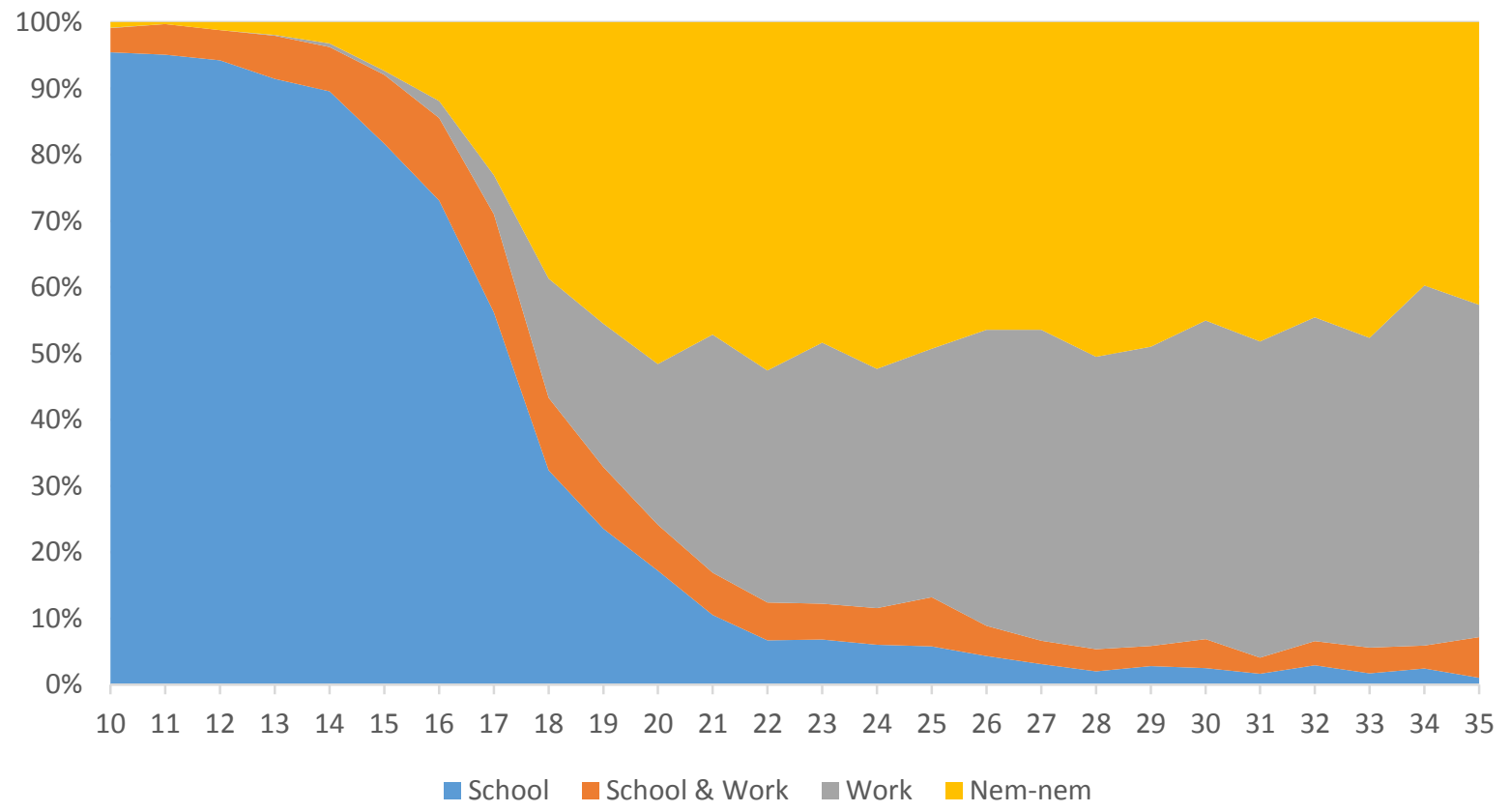

Source: Authors' calculation based on PNAD 2014 - IBGE. 
Another health measurement that meaningfully improved is maternal mortality, but it is nonetheless still marked by racial and geographic inequalities. Maternal mortality serves as a proxy for the adequate provision of health services for women, with discrepancies highlighting differences in access to medical care..$^{50}$ Thus, it is worrying that among the 1,465 maternal deaths registered by the Ministry of Health in 2014, 65 percent of the victims were Afro-Brazilian and 30 percent were white women, with the other 5 percent indigenous or women from other ethnic origins (SIM 2015). ${ }^{51}$ Geographic inequalities are also very pronounced, ranging from 36.9 deaths per 100,000 live births in Santa Catarina (South) to 101.8 deaths in Piauí (Northeast).

${ }^{50}$ These deaths are preventable in more than 90 percent of the cases (WHO 2001).

${ }^{51}$ A widely known case that illustrates these statistics is Alyne Pimentel, an Afro-Brazilian woman who died at 28 years old of complications resulting from her pregnancy after a health center in Rio de Janeiro failed to provide appropriate and timely emergency obstetric care. Pimentel could have survived if the health center had correctly diagnosed and treated her for intrauterine fetal death. The CEDAW Committee later held Brazil responsible for violating the CEDAW in her case and recommended a set of measures to compensate the family and improve health care for pregnant women across the country. (Source: http://www2.ohchr.org/english/law/docs/CEDAW-C-49-D-172008.pdf) 
Figures 10a, 10b. Incidence of Maternal Mortality, by State

\begin{tabular}{|c|c|c|}
\hline Region & State & $\begin{array}{c}\text { Maternal } \\
\text { mortality } \\
\text { (per 100,000) }\end{array}$ \\
\hline \multirow[t]{7}{*}{ North } & Rondônia & 71.3 \\
\hline & Acre & 41.4 \\
\hline & Amazonas & 93.9 \\
\hline & Roraima & 64.6 \\
\hline & Pará & 74.3 \\
\hline & Amapá & 59.5 \\
\hline & Tocantins & 96.1 \\
\hline \multirow[t]{9}{*}{ Northeast } & Maranhão & 114 \\
\hline & Piauí & 101.8 \\
\hline & Ceará & 73.4 \\
\hline & $\begin{array}{l}\text { Rio Grande do } \\
\text { Norte }\end{array}$ & 61.4 \\
\hline & Paraíba & 56.6 \\
\hline & Pernambuco & 63.3 \\
\hline & Alagoas & 55.1 \\
\hline & Sergipe & 90.1 \\
\hline & Bahia & 87.9 \\
\hline \multirow[t]{4}{*}{ Southeast } & Minas Gerais & 55.5 \\
\hline & Espírito Santo & 72.3 \\
\hline & Rio de Janeiro & 85.7 \\
\hline & São Paulo & 52.3 \\
\hline \multirow[t]{3}{*}{ South } & Paraná & 63.3 \\
\hline & Santa Catarina & 36.9 \\
\hline & $\begin{array}{l}\text { Rio Grande do } \\
\text { Sul }\end{array}$ & 55.7 \\
\hline \multirow[t]{4}{*}{ Mid-West } & $\begin{array}{l}\text { Mato Grosso do } \\
\text { Sul }\end{array}$ & 76.4 \\
\hline & Mato Grosso & 76.7 \\
\hline & Goiás & 61 \\
\hline & Distrito Federal & 48.7 \\
\hline
\end{tabular}

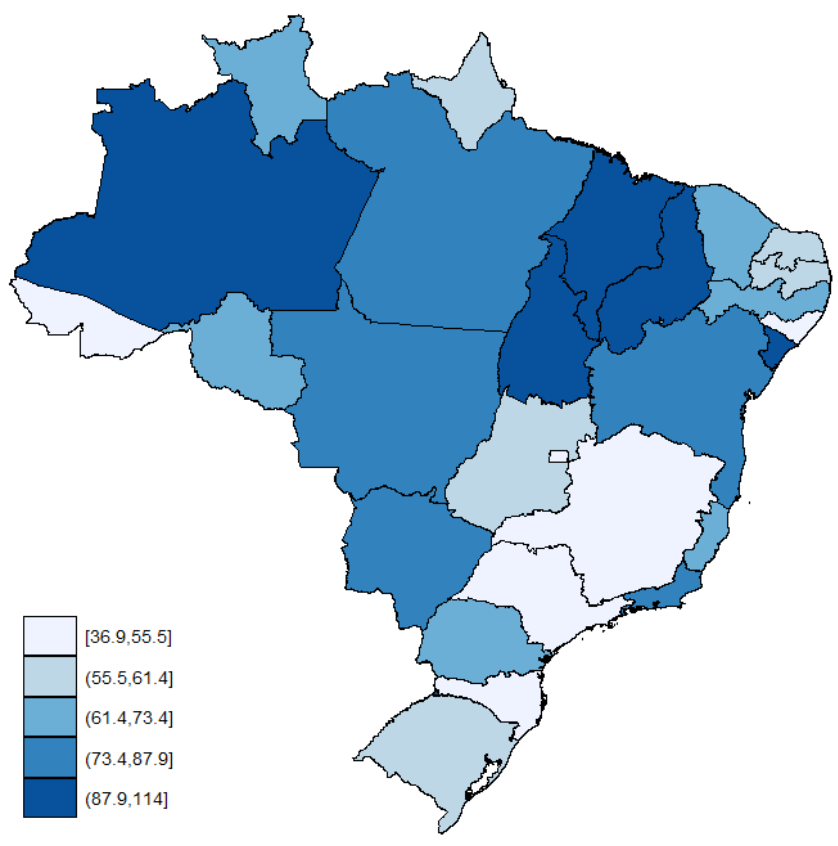

Source: Szwarcwald 2014.

In a related pattern, a 2012 survey found that $\mathbf{6 2 . 4}$ percent of children in Brazil were born to women who had seven or more pre-natal visits during pregnancy, indicating adequate care, but significantly lower shares of women of different racial backgrounds received such numbers of visits. Three-quarters of white children were born to mothers who had the seven or more prenatal visits, but only about half of Afro-Brazilian children and as little as one-quarter of indigenous children. Regional disparities are also 
significant: Women from the North and Northeast regions have less access to prenatal care than recommended: only 41 percent of the pregnant women from the North and 50.2 percent of the pregnant women from the Northeast region had seven or more visits (Brasil 2015b).

Box 1: Zika and Dengue Viruses

The spread of the mosquito-borne zika virus in Brazil has captured international attention over the last year, though dengue fever, also a mosquito-transmitted illness, has had a much higher incidence in Brazil. As mosquitos are the vector for both diseases, it is not surprising that their presence varies across regions, according to climactic differences. The Center-West has had the highest incidence of cases of both viruses in the first quarter of 2016. For the zika virus, the secondhighest level of incidence is in the Northeast, while for dengue it is in the Southeast of the country.

Table. Incidence of Zika and Dengue in 2016, by Region (probable cases per 100,000 people)

\begin{tabular}{|l|c|c|}
\hline Region & Zika & Dengue \\
\hline North & 36.0 & 162.7 \\
\hline Northeast & 53.5 & 279.8 \\
\hline Southeast & 41.4 & 540.9 \\
\hline South & 6.1 & 196.0 \\
\hline Center-West & 113.4 & 613.1 \\
\hline \multicolumn{1}{|c|}{ Total } & 44.7 & 392.5 \\
\hline
\end{tabular}

Note: Incidence rates are for January 3-April 2, 2016.

Source: Ministry of Health, Boletim Epidemiológico, vol. 47(18).

http://portalsaude.saude.gov.br/images/pdf/2016/abril/27/2016-014---Dengue-SE13-substitui----0.pdf

Importantly, although differences in the incidence of the two diseases may be due largely to climatic factors, the ability to cope with symptoms and risks are also likely different by region. States with better-equipped medical services and networks in terms of funding, staffing, supplies, and coverage are likely in a better position to confront the disease. These geographic differences in disease incidence and coping capacity have implications for women across the country. In-utero exposure to the zika virus has been linked with microcephaly and other several fetal brain defects, but access to prenatal care for identifying and monitoring any effects of exposure varies dramatically between subgroups of women, as do the financial resources and ability to care for a child with disabilities. Women are commonly the primary caretakers for children and other dependents in the household, and are more likely to take leave from work to care for any household member infected with zika or dengue, besides any other illnesses. This social norm contributes to the limited engagement of women with the labor force and the stability of their employment. 


\section{Economic Opportunities}

The over-all gender gap in labor force participation and employment has not changed substantially over the last decade, but there are important differences in LFP and employment across geographic areas. Racial differences in participation are small, with 56.2 percent of white and 55 percent of Afro-Brazilian women aged 15 and older participating in the labor force in 2013. In contrast, geography can have a major impact: women's LFP is below 50 percent in Alagoas, Pernambuco, Paraíba, Acre, and Sergipe, while it was over 60 percent in Rio Grande do Sul and Brasília (IBGE 2015). By region, labor force participation rates for women are highest in the South (60.7 percent) and lowest in the Northeast (53.7 percent).

\section{Graph 8. Labor Force Participation, by Gender and State (ages 15 and older)}

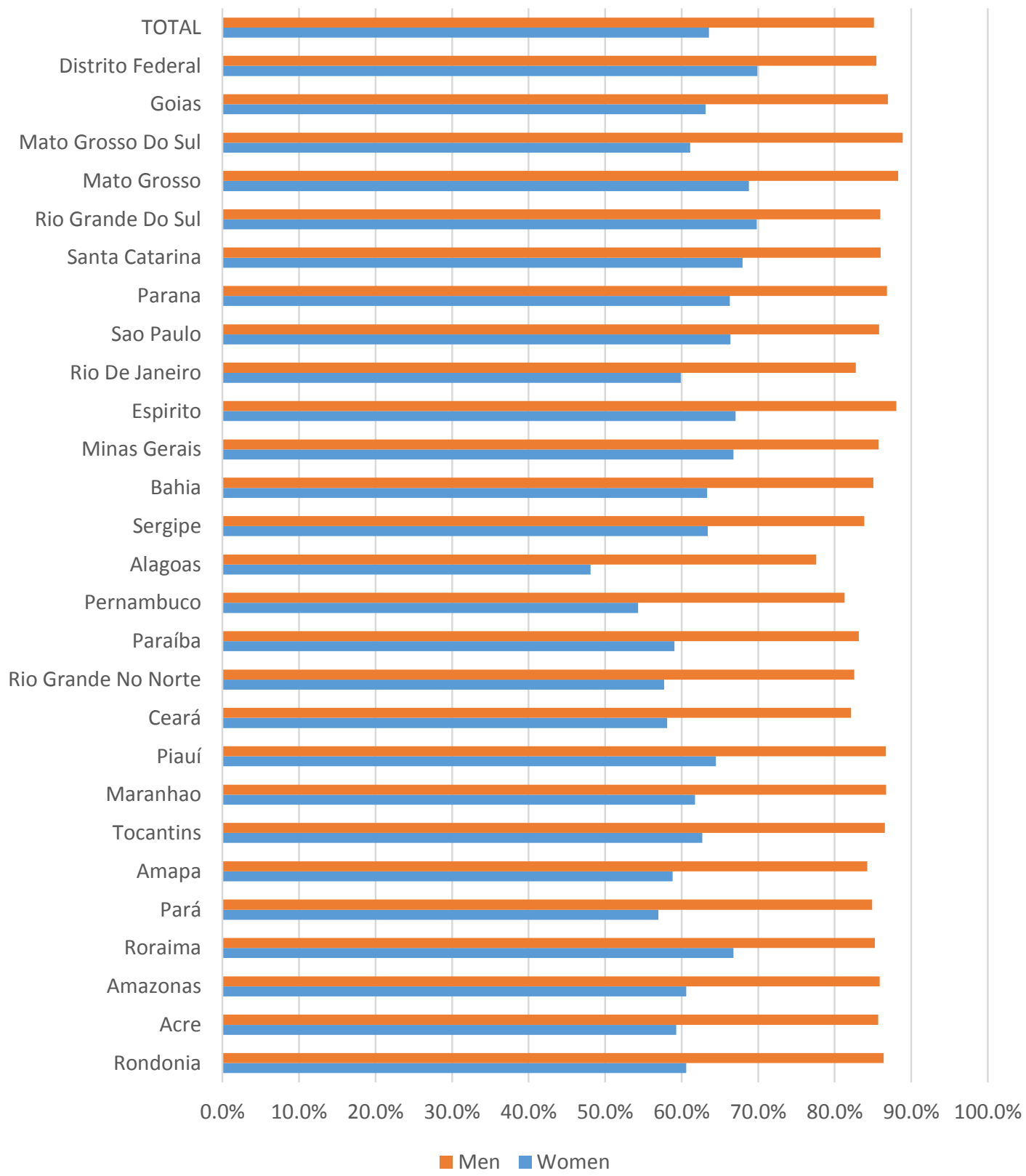


Other differences emerge concerning age and race. Among young adults 18-24 years of age, the share of men participating in the labor force is $\mathbf{1 7 . 6}$ percentage points higher compared to their female counterparts. Among those 45 to 59 years of age, the discrepancy is even greater, 25.1 percentage points (PNAD 2014). When adding race to the comparison, we see that LFP is higher among black and pardo Brazilians and lower among women, as shown by the negative coefficients below. However, the gender gap in LFP is larger among pardo men and women than among whites, and even smaller among the black population.

Table 2. Changes in labor force participation according to gender, race and their interaction

\begin{tabular}{rc}
\hline & Coef. \\
\hline Pardo & $0.030^{* * *}$ \\
Black & $(0.000)$ \\
& $0.023^{* * *}$ \\
Women & $(0.000)$ \\
& $-0.228^{* * *}$ \\
Pardo * Women & $(0.000)$ \\
& $-0.019 * * *$ \\
Black * Women & $(0.000)$ \\
& $0.012^{* * *}$ \\
& $(0.000)$ \\
\hline
\end{tabular}

Obs. Standard Errors in Parenthesis

Obs. $2 * * *$ significant at $1 \%$

Source: Authors' calculation based on PNAD-IBGE.

There are also significant differences in women's labor force participation compared by ethnicity or race. For instance, informality (the share of workers who do not have a carteira assinada, a formal contract) is much higher among Afro-Brazilians than whites or Asians. However, the share of female informal workers is highest among the indigenous. 


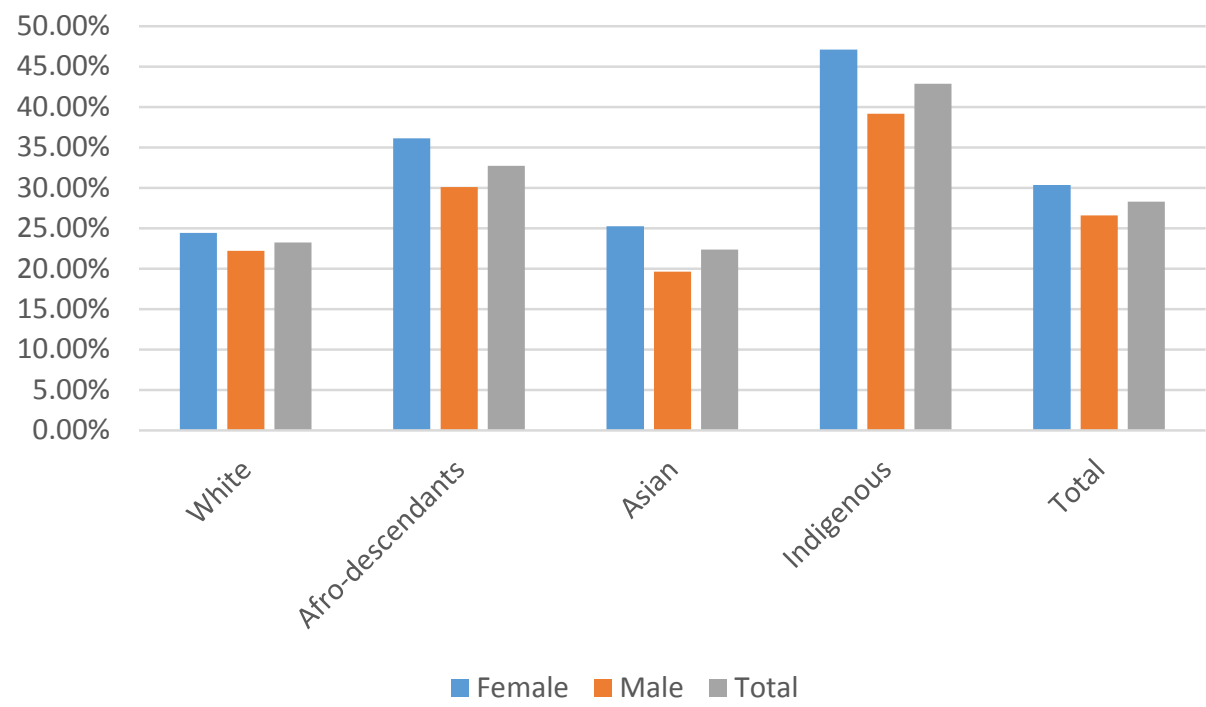

Source: Authors' calculations from PNAD 2014.

Wage gaps are a stark indicator of the economic limitations that black women face regardless of education level. Women's hourly wages are lower than men's at all levels of education, but the wages paid to Afro-Brazilian women are less than half those of white men. On average, Afro-Brazilian women earn 7.7 BRL per hour, compared to 12.5 BRL for white women and 15.6 BRL for white men. Among economically active adults who completed secondary education or higher, Afro-Brazilian women earn an average of $15.6 \mathrm{BRL}$ or less than half of the wage of white men with the same level of education, 32.7 BRL. These gaps reflect differences in economic opportunities by race and gender, with implications for gaps in endowments and labor force participation.

Table 2. Hourly wages by sex, race, and years of education, 2012 (Brazilian $R \$$ )

\begin{tabular}{|c|c|c|c|c|c|}
\hline Sex/ Race & $\begin{array}{l}\text { Up to } 4 \text { years } \\
\text { of education }\end{array}$ & $\begin{array}{l}\text { 5-8 years of } \\
\text { education }\end{array}$ & $\begin{array}{c}\text { 9-11 years of } \\
\text { education }\end{array}$ & $\begin{array}{l}12+\text { years of } \\
\text { education }\end{array}$ & Total \\
\hline Women & 5.4 & 6.2 & 7.6 & 19.6 & 10.2 \\
\hline White & 6.8 & 6.6 & 8.5 & 21.5 & 12.5 \\
\hline Afro-Brazilian & 4.5 & 5.8 & 6.8 & 15.6 & 7.7 \\
\hline Men & 6.4 & 8.1 & 11.1 & 29.6 & 12.2 \\
\hline White & 7.4 & 9.2 & 12.8 & 32.7 & 15.6 \\
\hline Afro-Brazilian & 5.8 & 7.3 & 9.5 & 22.0 & 9.0 \\
\hline Total & 6.1 & 7.4 & 9.6 & 24.2 & 11.3 \\
\hline
\end{tabular}

Source: Brasil 2015b

Note: Wages for economically active population 16 years and older.

Segregation in certain economic sectors has also limited women's opportunities, because the sectors tend to have lower growth potential and higher levels of informality. A stark indicator of the degree of segregation in Brazil is domestic work, in which 13.4 percent of all employed women aged 20-50 across 
the country are employed, in contrast to 0.8 percent of men. Employment in this sector varies slightly between regions, but black/parda women are much more likely to be domestic workers than are white women in each of the five regions. While between 6 and 7 percent of employed white women work as domestic workers in each region, the share of Afro-Brazilian women in that sector is twice as high in the South, Southeast, and Center-West.

Graphs 10a and 10b. Domestic Workers as Share of All Women and of Working Women, ages 20-50

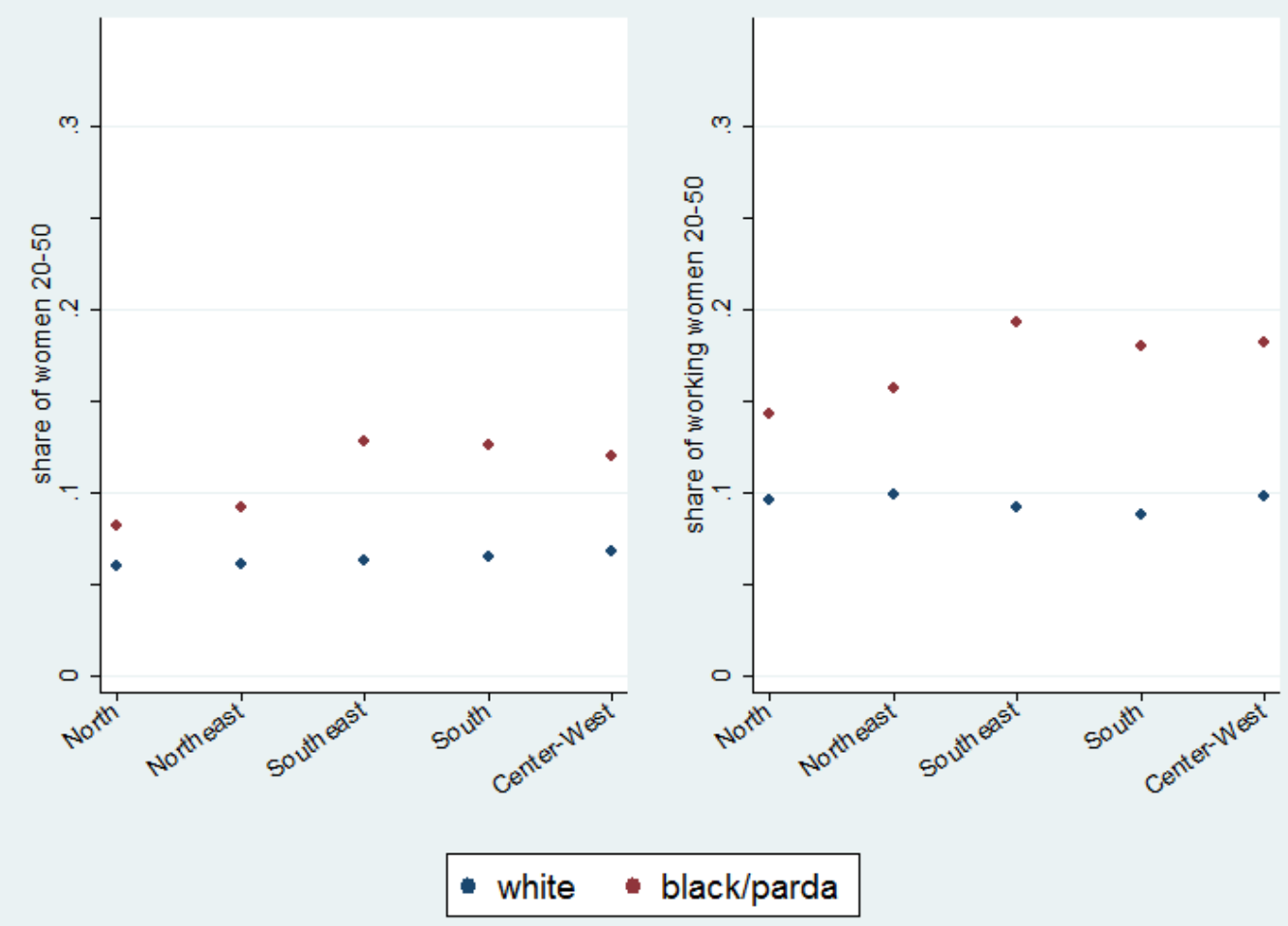

Source: Authors' calculations from PNAD 2014.

Note: Shares are calculated per women of each race and in each region.

\section{Agency}

Teenage pregnancy is an integral indicator of young women's agency, reflecting gender-based social expectations, lack of access to information and safe, effective, affordable and acceptable contraception, and lack of capacity to refuse or negotiate safe sex with a male partner (Sen and Batliwala 2000, Chacham et al. 2012, World Health Assembly 2012). In addition, it undermines personal development and ability of the individual to make present and future choices. Combined with a shortage and inadequacy of childcare services and lack of family support, teenage pregnancy may also result in health problems, higher rates of school dropout, difficulties in finding and keeping a job, and lower incomes (World Health Assembly 2012).

As in other Latin American countries, high rates of adolescent pregnancy in Brazil are associated with high social vulnerability and poverty. Teenage women who are Afro-brazilian and/or live in poor urban 
and rural areas are significantly more exposed to the risk of early pregnancy (Chacham et al. 2012 and Fontoura and Pinheiro 2008). This arises from lower access to information, contraception, health services, and safe abortions. Discrepancies in women's access to educational and economic opportunities as well as their incapacity to take full control over their bodies and life plans may also affect fertility outcomes before the age of 20 (Azevedo et al. 2012). It is important to highlight that, especially among poor women, teenage pregnancy tends to heighten dependency on the income of parents or partners. Moreover, recent studies associate precocious reproductive behavior with lower levels of education and income, both for men and women (Heilborn et al. 2002). Differences in the perception of pregnancy, maternity, and youth across social classes and groups also play an important role, since, in the absence of perspectives on educational and professional attainments, poor adolescent women show a higher tendency to view childbearing as a turning point into adulthood (Fontoura and Pinheiro 2008).

In Brazil, the adolescent fertility rate (births per 1,000 women ages 15-19) has steadily decreased since the beginning of this century. It stood at 87.47 in 2000 and declined to 70.00 in 2013. But it remains slightly above the average level for LAC, 67.7 in 2013 (World Bank 2015).

The rural/urban divide is also relevant in the incidence of teenage pregnancy, and rural/urban differences can also be found within regions. Nationally, 10.5 percent of women 15-19 living in urban areas have had at least one child, compared to 13.2 percent in rural areas. In the North, the shares are 14.9 percent in urban and 18.9 percent in rural areas. The Southeast, in contrast, has not only a lower overall rate of teenage pregnancy, but also a smaller rural/urban gap: 9.3 percent of 15-19-year-old women in urban areas and 10.0 percent of those in rural areas report having had at least one child (IBGESIDRA 2014).

Graph 11. Women aged 15-19 delivering live births, as a share of all women 15-19, by region and year

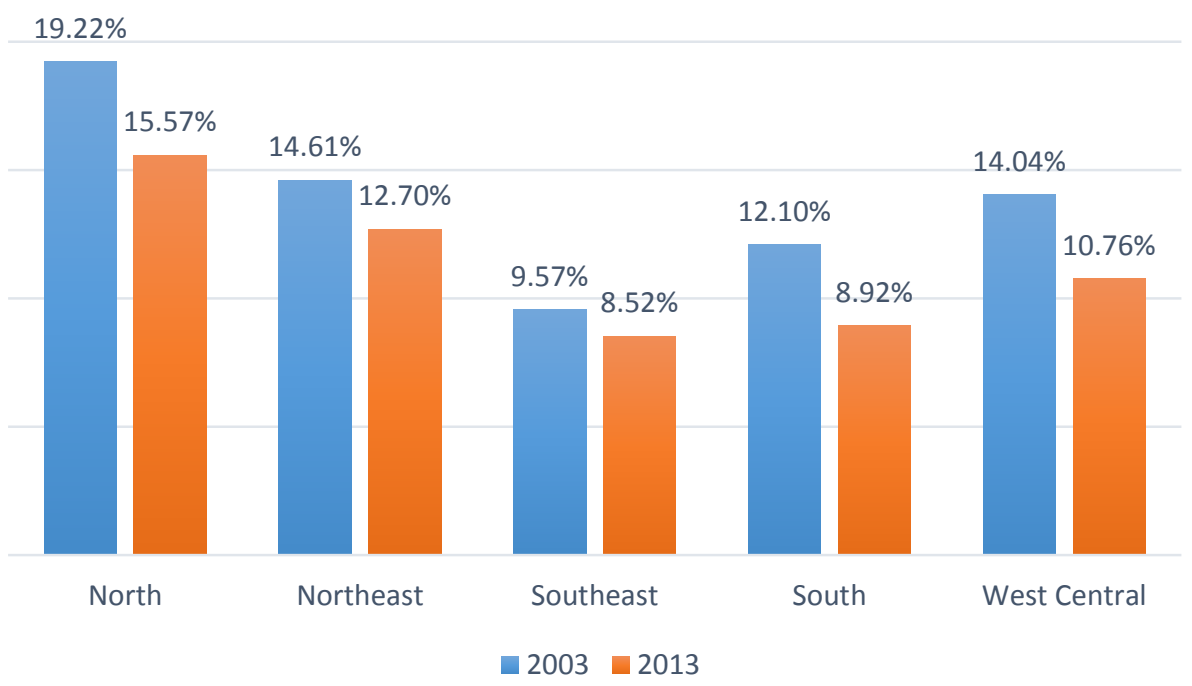

Source: Authors' calculation based on PNAD 2014 - IBGE. 
Notably, a substantial portion of teenage pregnancies occurs within marriage or relationships with cohabitation, though there are racial and regional differences in that metric as well. In 2014, 14 percent of women 15-19 years of age reported living with a spouse or partner, and another 4.5 percent had previously lived with a spouse or partner. This was most common the North, where 16.2 percent of white and 19.0 percent of black/pardo teenage women in that age group lived with a spouse or partner. Interestingly, having a child, however, is not necessarily the main driver of this early cohabitation or marriage, particularly for black/pardo women. In the North, 10.3 percent of white teenagers live with a spouse or partner and have a child; the respective share is 8.4 percent for black/pardo women.

Graph 12. Share of Married or Cohabitating Women, 15-19 years of age, by race and region

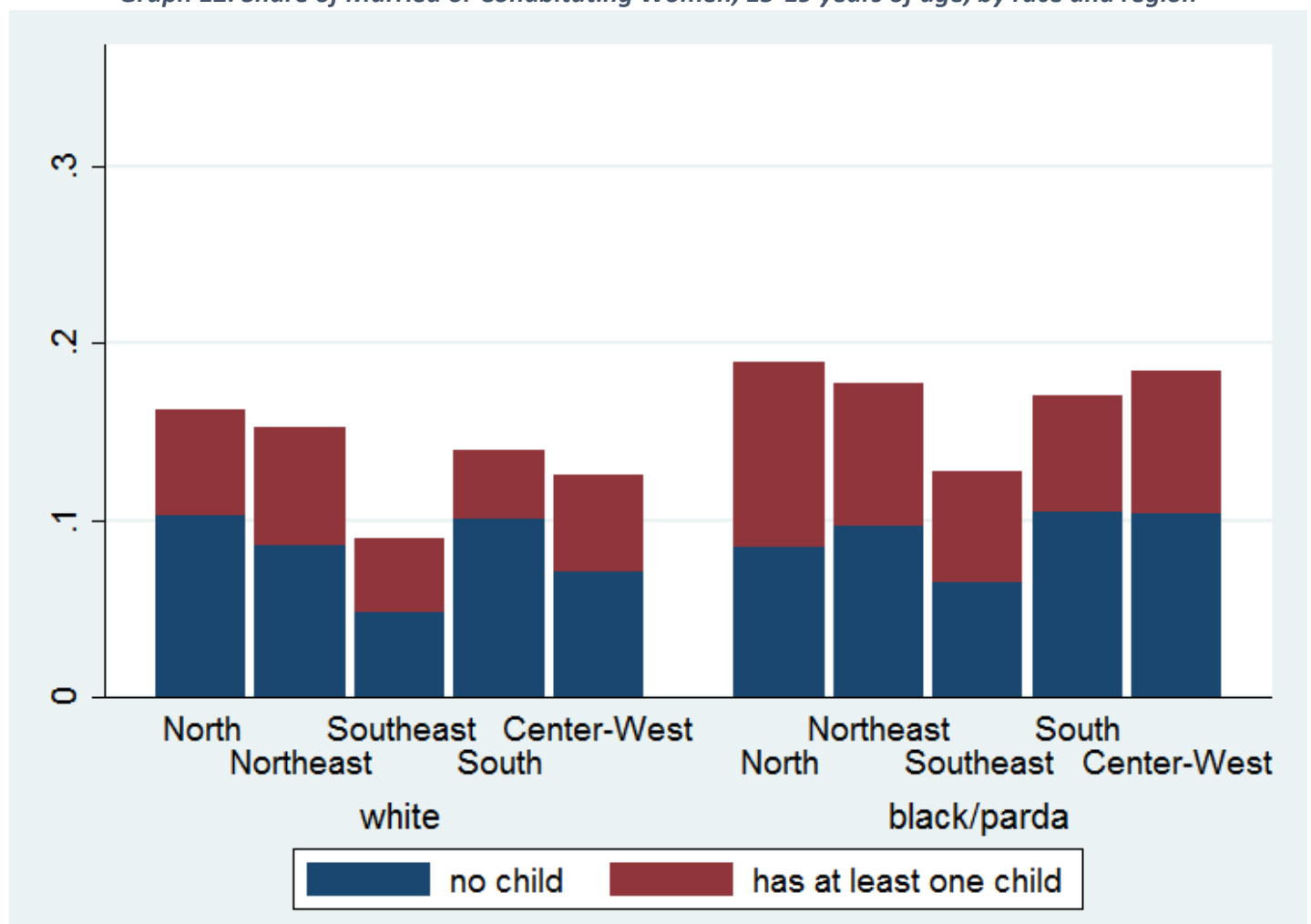

Source: Authors' calculations from PNAD 2014.

Note: Bar height is the share of women 15-19 within each category who live with a husband or partner, distributed between those who have had a child and those who did not (regardless of child's place of residence).

Finally, as observed in most countries for which data are available, the incidence of teenage pregnancy decreases with an increase in socio-economic status. The following graph illustrates that pattern: 
Figure 11. Share of girls aged 15-19 who had a child or have lost a baby after at least seven months of pregnancy, by income quintile

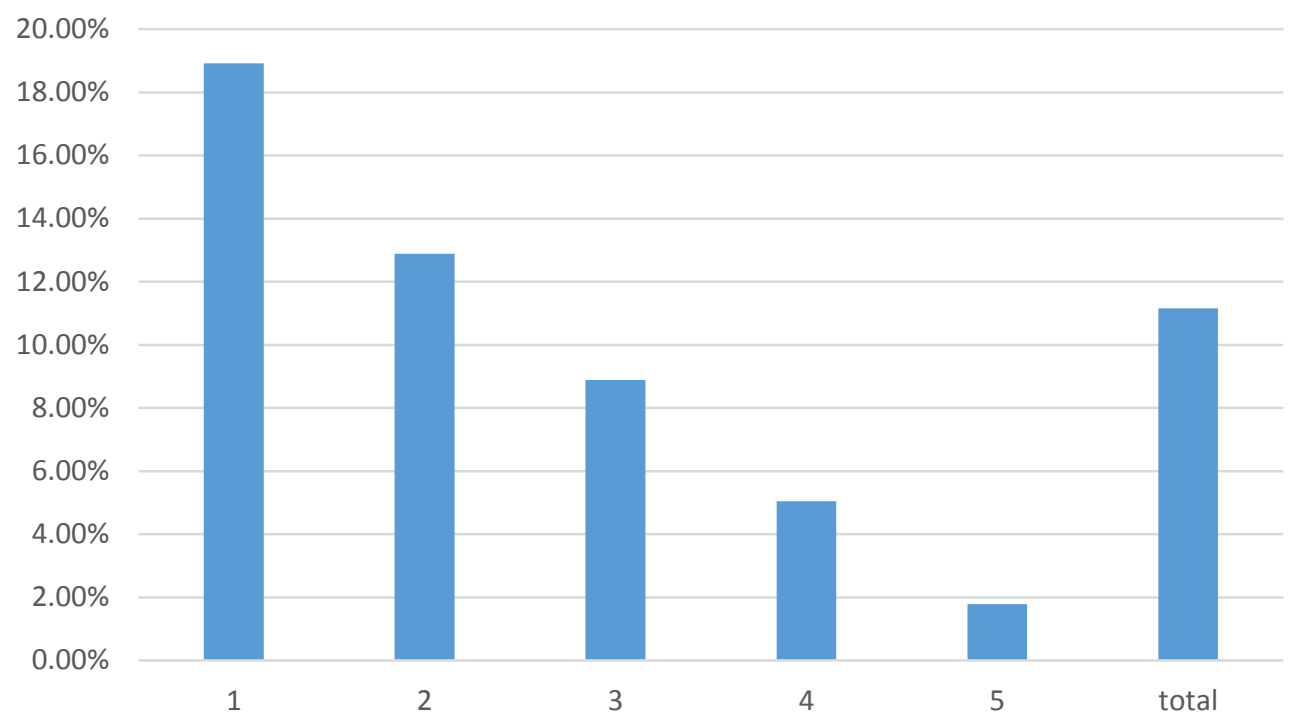

Source: Authors' calculations from PNAD 2014.

Another indicator that shows differences by race and region is gender-based violence. Brazil has the fifth-highest female homicide rate among 83 countries, and the risk is not evenly distributed across race or place of residence. In fact, if the Center-West were treated as a country, its female homicide rate of 7.0 per 100,000 would place it second among the 83 countries. Afro-Brazilian women in the region face an even higher rate, 8.2 per 100,000. In contrast, the homicide rate for white women is only half as high. Similar racial differences in the female homicide rate can be found across the four regions, with the South as an exception.

The Southeast has the lowest rate of murder of women in the country, having been the only region to register a decline in the decade between 2003 and 2013. In contrast, the rate increased by over 70 percent in both the North and Northeast during the same period. The growth was concentrated among Afro-Brazilian and indigenous women, particularly in the Northeast, where the rate for Afro-Brazilian women increased 103 percent.

Table 3. Female Victim Homicide Rate (per 100,000), by Region and Race

\begin{tabular}{|c|c|c|c|c|c|}
\hline Region & $\begin{array}{c}\text { Homicide Rate, } \\
\text { All Women, } \\
2003\end{array}$ & $\begin{array}{c}\text { Homicide Rate, } \\
\text { All Women, } \\
2013\end{array}$ & $\begin{array}{c}\text { \% change in HR, } \\
\text { All Women, } \\
\text { 2003-2013 }\end{array}$ & $\begin{array}{c}\text { Homicide Rate, } \\
\text { White Women, } \\
2013\end{array}$ & $\begin{array}{c}\text { Homicide Rate } \\
\text { Black Women, } \\
2013\end{array}$ \\
\hline North & 3.5 & 6.1 & $75.8 \%$ & 3.5 & 6.0 \\
\hline Northeast & 3.2 & 5.6 & $75.2 \%$ & 2.3 & 5.8 \\
\hline Southeast & 5.4 & 3.8 & $-29.3 \%$ & 2.9 & 4.4 \\
\hline South & 3.6 & 4.2 & $16.6 \%$ & 4.1 & 3.4 \\
\hline Center-west & 5.8 & 7.0 & $20.3 \%$ & 4.0 & 8.2 \\
\hline Total & 4.4 & 4.8 & $8.8 \%$ & 3.2 & 5.4 \\
\hline
\end{tabular}

Source: FLACSO 2015, Mapa da Violência. 
The metropolitan areas of state capitals tend to have more services for female victims of gender-based violence than do remote and rural areas. Though the number of service points in the SPM network (e.g., CEAMs, DEAMs, shelters, specialized courts) has increased rapidly, in 2013 only one-fifth of all municipalities, primarily urban, were served by the network. Due to budget constraints and political priorities, services tend to be lacking in rural areas and remote areas (Campos 2012).

Indigenous women are especially vulnerable to violence. In 2012, the average homicide rate among Brazilian women was 4.6 per 100,000. But the rate was almost twice as high among indigenous women: 7.3 per 100,000 . Also, the suicide rate among indigenous women was as high as 5.8 per 100,000 , more than twice as high as the average 2.2 rate for the female population as a whole (Brasil 2015b). Beyond gender-based violence, the intensification of conflicts over land in indigenous areas appears to have driven up the number of killings of indigenous women (CPT 2014)..$^{52}$

\footnotetext{
52 According to data published by Comissão Pastoral da Terra, (Pastoral Commission of the Land) there has been a small but steady increase in the number of indigenous women murdered in consequence of land and water conflicts. While there was no register of indigenous women being murdered in this context in 2010 and 2011, they were reported to be 3 percent of the persons killed in such conflicts in 2012 and 6 percent in 2013 and 2014. For an overview of violence against indigenous populations and conflicts with agri-businesses, see Relatório: Violência contra os Povos Indígenas no Brasil - Dados de 2013 (CIMI, 2014).
} 


\section{Conclusion: For Further Progress, Address Disparities among Women}

Feminist and women's movements have played a critical role in pushing forward the public agenda on gender equality and women's rights in Brazil. The Government of Brazil has demonstrated a commitment to these issues in recent decades, with the creation of SPM in 2003 and subsequent initiatives. Federal, state, and municipal government have used participatory forums, deliberative venues, and plans to engage civil society in the drafting of policy guidelines and public priorities. Significant achievements have resulted over the last two decades in both the legal and institutional arenas, some of which, notably the Maria da Penha Law, have set Brazil as a model for other countries.

However, mainstreaming gender into policies remains a challenge, particularly in light of the relatively small budgets and recent demotion of SPM from its ministerial status. Implementation of the Maria da Penha Law, for example, has slowed due to lack of political prioritization, funding, and capacity at the municipal levels. In fact, although all states have a dedicated government institution for gender equality, most of these bodies remain at the margin of the political agenda, with limited resources and political power to implement policies or projects.

Nevertheless, Brazil has made important advances in several areas of gender equality, particularly endowments. The gap between women's and men's education has largely closed, and in some metrics, such as participation in higher education, women have even surpassed men. Similarly, though it has not met the Millennium Development Goal on maternal health, Brazil has had substantial success in decreasing maternal mortality, increasing the share of births attended by physicians, and ensuring access to contraceptives. The incidence of teenage pregnancy has also decreased over the last decade.

Women's economic opportunities and agency, however, remain limited in Brazil. Not only are female labor force participation and employment lower than those of men, but differences in wages and time use remain. A related factor holding back women's economic opportunities and returns to education affects youth and young adults is the so-called "nem-nem" phenomenon: At every age between 18 and 35 , roughly one-third of women are neither in work nor in school. This share is much lower for men, as from age 25 onward only one in ten men are equally disengaged from the labor force and education.

In Brazil, gender issues are inherently intertwined with race, ethnicity, and socio-economic background, and considering these identities and their influence on disadvantage is crucial when assessing how to address gender inequality in Brazil. In issues that have achieved considerable progress, such as education and health, Afro-Brazilian, indigenous women, and women in the North, Northeast and Center-West have worse outcomes than female averages. And in issues where women as a whole still face substantial disadvantages, particularly economic opportunities and agency, addressing the additional gaps that these sub-groups of women face is an integral step for gender equality.

Wages earned by Afro-Brazilian women, for instance, are lower than those of white women, and sometimes just half of those paid to white men with the same education level, disparities that have direct implications for labor force participation, employment, and education. This discrepancy exists at 
every level of education, leading to lower actual and expected returns to education for Afro-Brazilian women and discouraging educational attainment and engagement with the labor market. To close the gender gap in labor force participation, employment, and time use, it is important to both combat segregation in training and employment and close the racial gap in wages.

Addressing racial and geographic differences in both victimhood and access to protection and support is paramount for tackling gender-based violence in Brazil. A comprehensive effort for addressing genderbased violence, for example, must include measures to decrease the higher rates of deadly violence facing Afro-Brazilian women and the lower coverage of care in the North and Northeast of the country. The reach of services must extend outside urban areas. The obstacles currently holding up the implementation and expansion of the Maria da Penha Law point to other urgently needed next steps, such as training of personnel to eliminate social acceptance of GBV and racism, and a higher political and financial priority for provision of services in certain municipalities and states. 


\section{References}

Agénor, P., and O. Canuto. 2013. "Gender Equality and Economic Growth in Brazil." World Bank - Economic Premise, issue 109, pp. 1-5, March, 2013. Washington, DC: The World Bank.

Aizer, A. 2011. "Poverty, Violence, and Health: The Impact of Domestic Violence during Pregnancy on Newborn Health." Journal of Human Resources, vol. 46(3):518-538.

Alvarez, S. 1999. "Advocating feminism: The Latin American Feminist NGO 'Boom.'” International Feminist Journal of Politics, 1(2):181-209.

Alvarez, S. 2000. "Translating the global: Effects of transnational organizing on local feminist discourses and practices in Latin America." Cadernos de Pesquisa PPGSP/UFSC, n. 22.

Atal, J.P., H. Ñopo, and N. Winder. 2009. "New Century, Old Disparities: Gender and Ethnic Wage Gaps in Latin America." IDB Working Paper Series No. 109. Washington, DC: The Inter-American Development Bank.

Azevedo, J.P., M. Favara, S. Haddock, L.F. Lopez-Calva, M. Müller, and E. Perova. 2012a. "Teenage Pregnancy and Opportunities in Latin America and the Caribbean: A study on early pregnancy, poverty and economic achievements." Washington, DC: The World Bank.

Azevedo, J.P., and M. Favara. 2012b. "The Impact of Bolsa Familia on the Incidence of Teenage Pregnancies in Brazil." Background Paper for the World Bank Regional Study on Teenage Pregnancy (Azevedo et al 2012a).

Bairros, L. 1995. "Nossos feminismos revisitados." Revista Estudos Feministas, 3(2), 458-463.

Banco Nacional para o Desenvolvimento Econômico e Social (BNDES). 2015. Pronaf Mulher. Available at: http://www.bndes.gov.br/SiteBNDES/bndes/bndes pt/Institucional/Apoio Financeiro/Programas e Fundos/pronaf mulher.html

Boiteux, L., and J.P. Pádua. 2013. A desproporcionalidade da lei de drogas. Os custos humanos $e$ econômicos da atual política do Brasil. CEDD - Coletivo de Estudos Drogas e Direito: Rio de Janeiro.

Brasil. Ministério da Saúde. 2004. Política Nacional de Atenção Integral à Saúde da Mulher: princípios e diretrizes / Ministério da Saúde, Secretaria de Atenção à Saúde, Departamento de Ações Programáticas Estratégicas. - Brasília: Ministério da Saúde. Available at: http://bvsms.saude.gov.br/bvs/publicacoes/politica nac atencao mulher.pdf

Brasil. Câmara dos Deputados. 2013. Relatório Final da Comissão Parlamentar Mista de Inquérito (CPMI) da Violência Doméstica. Brasília.

Brasil. Secretaria de Políticas para as Mulheres. 2014. Relatório Anual Socioeconômico da Mulher 2013. Brasilia: Secretaria de Políticas para as Mulheres.

Brasil. Secretaria de Políticas para as Mulheres. 2015a. Balanço 2014 - Ligue 180. Brasília-DF: SPM.

Brasil. Secretaria de Políticas para as Mulheres. 2015b. Relatório Anual Socioeconômico da Mulher (RASEAM) 2014. Brasilia: Secretaria de Políticas para as Mulheres.

Bruschini, M.C.A. 2007. "Work and Gender in Brazil in the Last Ten Years." Cadernos de Pesquisa 37(3): 537-72.

Campos, C.H. 2016. "Challenges to the Implementation of the Maria da Penha Law." Working Paper 2(2). Oxford, UK: Oxford Human Rights Hub. 
CEPAL. 2011. "Observatory: Gender Equality in Latin America and the Caribbean." Statistics. Santiago de Chile, Chile.

CFEMEA. 2014. Execução das políticas públicas ainda é insuficiente para garantia de direitos. Brasília-DF: CFEMEA. Available at:

http://www.cfemea.org.br/index.php?option=com content\&view=article\&id=4497:execucao-daspoliticas-publicas-ainda-e-insuficiente-para-garantia-de-direitos\&catid=410:numero-176-outubrode-2014\&Itemid $=129$

CFEMEA. 2015. Tolerância Institucional à Violência contra as Mulheres. Brasília: CFEMEA.

Chaaban, J., and W. Cunningham. 2011. "Measuring the Economic Gain of Investing in Girls: The girl effect dividend." Washington, DC: The World Bank.

Chacham, A.S., M.B. Maia, and M.B. Camargo. 2012. "Autonomia, gênero e gravidez na adolescência: uma análise comparativa da experiência de adolescentes e mulheres jovens provenientes de camadas médias e populares em Belo Horizonte." Rev. bras. estud. popul. 2012, vol. 29, n. 2, pp. 389-407.

$\mathrm{CIMI}$ - Conselho Indigenista Missionário. 2014. Relatório: Violência contra os Povos Indígenas no Brasil Dados de 2013. Brasília-DF.

Comissão Organizadora da Conferência Nacional de Mulheres Brasileiras. 2002. Plataforma Política Feminista. Brasilia. Available at: http://www.cfemea.org.br/images/stories/pdf/ppfcnmb.pdf.

Comissão Pastoral da Terra. 2014. Conflitos no Campo - Brasil 2014. Goiânia: CPT Nacional.

Committee on the Elimination of Discrimination against Women (CEDAW). 2011. Forty-ninth session. Available at: http://www2.ohchr.org/english/law/docs/CEDAW-C-49-D-17-2008.pdf

Conectas. 2015. Mulheres encarceradas: dupla punição. Available at: http://www.conectas.org/pt/acoes/justica/noticia/28793-mulheres-e-encarceradas-dupla-punicao

Correio 24 horas. 2014. Presas enfrentam o drama da separação dos filhos. Available at: http://www.correio24horas.com.br/detalhe/noticia/presas-enfrentam-o-drama-da-separacao-dosfilhos/?cHash=0f57fcb6ee58ab891061ab1b6d2cde8c

Costa, A.M. 1996. Planejamento familiar no Brasil. Bioética, n. 4, v. 2, pp. 209-215.

Costa, A.M., D. Guilhem, and L.D. Silver. 2006. Planejamento Familiar: a autonomia das mulheres sob questão. Revista Brasileira de Saúde Materno Infantil, n. 6, v. 1. pp. 75-84.

Cunningham, W., L. McGinnis, R. García Verdú, C. Tesliuc, and D. Verner. 2008. "Youth at Risk in Latin America and the Caribbean: Understanding the Causes, Realizing the Potential." Washington, DC: The World Bank.

Data Popular and SOS Corpo. 2012. Creche como demanda das mulheres por políticas públicas. São Paulo/Recife, Data Popular/SOS Corpo.

Diniz, D., and M. Medeiros. 2010. Aborto no Brasil: uma pesquisa domiciliar com técnica de urna. Rio de Janeiro. Revista Ciência \& Saúde Coletiva, 15(1):959-966.

ECMIA (Continental Network of Indigenous Women of the Americas) 2013: "Violence and Indigenous Women." Available at: http://www.ncdsv.org/images/Ecmia-Chirapaq Violence-and-IndigenousWomen 3-2013.pdf 
Fontoura, N., and L. Pinheiro. 2008. "Síndrome de Juno: gravidez, juventude e políticas públicas." In: J.A. Castro and L. Aquino (Orgs.). Juventudes e políticas sociais no Brasil. Brasília: Ipea (Texto para discussão, n. 1335).

Fundação Perseu Abramo. 2010. Violência contra a Mulher na Esfera Pública e Privada. São Paulo: Fundação Perseu Abramo; SESC.

GTZ, World Bank, and Inter-American Development Bank. 2010. "Women's Economic Opportunities in the Formal Private Sector in Latin America and the Caribbean: A Focus on Entrepreneurship." Washington, DC: The World Bank.

Human Rights Watch: World Report 2014. Available at: https://www.hrw.org/sites/default/files/wr2014_web_0.pdf

IBGE. 2011. Estatísticas do Registro Civil. Available at: http://seriesestatisticas.ibge.gov.br/series.aspx? no=10\&op=0\&vcodigo=RC63\&t=casamento-faixaetaria-mulheres

IBGE. 2014a. Pesquisa de Informações Básicas Municipais (MUNIC) - 2013. Brasília-DF: IBGE.

IBGE. 2014b. Pesquisa de Informações Básicas Estaduais (ESTADIC) - 2013. Brasília-DF: IBGE.

IBGE. 2015. Pesquisa Nacional de Amostra por Domicílio (PNAD) - 2013. Brasília-DF: IBGE. Available at: http://www.ibge.gov.br/home/estatistica/populacao/trabalhoerendimento/pnad2013/microdados. shtm

IBGE. 2016. Pesquisa Nacional de Amostra por Domicílio (PNAD) - 2014. Brasília-DF.

ILO. 2015. ILOSTAT. Available at: http://www.ilo.org/ilostat

Instituto Avante Brasil. 2013. O Sistema Penitenciário Brasileiro em 2013. Available at: http://d2kefwu52uvymq.cloudfront.net/uploads/2015/02/LEVANTAMENTO-SISTEMAPENITENCIÁRIO-2013-JUNHO2.pdf

Kelley, D.J., C.G. Brush, P.G. Greene, and Y. Litovsky. 2013. Global Entrepreneurship monitor: 2012 Women's Report. Boston: The Center for Women's Leadership at Babson College and London Business School.

Leal, M.C. 2013. Nascer no Brasil: sumário executivo temático da pesquisa. Rio de Janeiro: Fundação Oswaldo Cruz.

Observatório do PNE. Metas do PNE: 1 - Educação Infantil. Available at: http://www.observatoriodopne.org.br/metas-pne/1-educacao-infantil

Lisboa, T.K. 2010. Violência de gênero ou feminicídio? Leis sobre violência e propostas de políticas públicas no Brasil e no México. In: RIAL, Carmen; PEDRO, Joana M.; AREND, Sílvia M. F. (Coord.). Diversidades: dimensões de gênero e sexualidade. p. 61-79. Ilha de Santa Catarina: Mulheres.

Lyra da Fonseca, J.L.C. 2008. Homens, Feminismo e Direitos Reprodutivos no Brasil. Tese (Doutorado em Saúde Pública) - Fundação Oswaldo Cruz: Recife.

Monteiro, J. 2013. Quem são os jovens nem-nem? Uma análise sobre os jovens que não estudam e não participam do mercado de trabalho. Texto para discussão $\mathrm{n}^{\circ} 34$. IBRE

Observatório do PNE. 2015. Metas do PNE: 1 - Educação Infantil. Available at: http://www.observatoriodopne.org.br/metas-pne/1-educacao-infantil 
Organisation for Economic Co-operation and Development. 2015. Social Institutions and Gender Index. Available at: http://genderindex.org/sites/default/files/pdfs/BRA.pdf

Pasinato, W. 2011. Femicídios e as mortes de mulheres no Brasil, Cadernos Pagu [online]. 37:219-246. Available at: http://www.compromissoeatitude.org.br/wpcontent/uploads/2014/04/PASINATO_Femicidios2011.pdf

Perova, E., S. Reynolds, and M. Müller. 2012: Towards a More Comprehensive Domestic Violence Policy in Brazil. World Bank.

Pines, A.M., M. Lerner, and D. Schwartz. 2010. "Gender differences in Entrepreneurship: Equality, Diversity and Inclusion in Times of Global Crisis." Equality, Diversity and Inclusion: An international Journal, 29(2):186-198.

Pinzani, A., and W. Rego. 2014. "Vozes do Bolsa-Família: autonomia, dinheiro e cidadania." São Paulo: Editora Unesp.

Powers, J., and B. Magnoni. 2010. "A Business to Call Her Own: Identifying, Analyzing and Overcoming Constraints to Women's Small Businesses in Latin America and the Caribbean." Washington, DC: The Inter-American Development Bank.

Szwarcwald, C.L., J.J.C. Escalante, D.L. Rabello Neto, P.R.B. de Souza Junior, and C.G. Victora. 2014. "Estimação da razão de mortalidade materna no Brasil, 2008-2011." Cadernos de Saúde Pública, 30(1):S71-S83.

Segato, R.L. 2006 ¿Qué es un feminicidio? Notas para un debate emergente. Série Antropologia no 401, UNB, Brasília.

Sen, G., and S. Batliwala. 2000. "Empowering Women for Reproductive Rights." In H.B. Presser and G. Sen, editors, Women's Empowerment and Demographic Processes. Oxford: Oxford University Press.

Soares, V. 1998. Muitas faces do feminismo no Brasil. In: Borba, A.; FariaA, N. \& Godinho, T. (orgs.). Mulher e política: gênero e feminismo no Partido dos Trabalhadores. São Paulo: Fundação Perseu Abramo.

Suarez, M., et al. 2006: "The Bolsa Família Programme and the Tackling of Gender Inequalities." Report to Brazilian Ministry of Social Development and Fight Against Hunger (MDS) and DFID, Brasilia.

Tas, E.O., M. Reimao, and M. Orlando. 2013: "Gender, ethnicity and cumulative disadvantage in education: Evidence from Latin American and African censuses." Policy Research Working Paper. Washington, DC: The World Bank.

TSE - Tribunal Superior Eleitoral. 2014. Data available at: http://www.tse.jus.br/eleicoes/estatisticas/estatisticas-eleitorais-2014.

Waiselfisz, J.J. 2015. Mapa da Violência 2015: Homicídio de mulheres no Brasil. Brasília: FLACSO Brasil.

World Health Organization. 2001. "Maternal Mortality at the end of a decade: Signs of progress?" Available at: http://www.who.int/bulletin/archives/79\%286\%29561.pdf.

World Health Organization. 2005. "Multi-country study on Women's Health and Domestic Violence against Women, 2005." Available at:

http://www.who.int/gender/violence/who_multicountry_study/en/

World Bank. 2009. “Women's Economic Opportunities in the Formal Private Sector in Latin America and the Caribbean-A Focus on Entrepreneurship." Washington, DC: The World Bank. 
World Bank. 2012a. "World Development Report 2012: Gender Equality and Development." Washington, DC: The World Bank.

World Bank. 2012b. "The Effect of Women's Economic Power in Latin America and the Caribbean." Washington, DC: The World Bank.

World Bank. 2014: "Voice and Agency: Empowering Women and Girls for Shared Prosperity." Washington, DC: The World Bank.

World Bank. 2015. World Development Indicators. Available at: data.worldbank.org/data-catalog/worlddevelopment-indicators

World Health Assembly. "Early marriages, adolescent and young pregnancies." Report by the Secretariat, 65, Geneva: World Health Organization, 2012.

Yount, K.M., A.M. DiGirolamo, and U. Ramakrishnan. 2011. "Impacts of domestic violence on child growth and nutrition: A conceptual review of the pathways of influence." Social Science \& Medicine, 72(9), 1534-1554. 
Annex: Number of Specialized Services for Victims of Domestic Violence by State and Type, 2013.

\begin{tabular}{|c|c|c|c|c|c|c|c|c|c|c|c|}
\hline $\begin{array}{l}\text { Type of } \\
\text { specialized } \\
\text { service }\end{array}$ & $\begin{array}{c}\text { Police } \\
\text { stations for } \\
\text { assisting } \\
\text { women }\end{array}$ & $\begin{array}{c}\text { Women's } \\
\text { assistance } \\
\text { divisions } \\
\text { in regular } \\
\text { police } \\
\text { stations }\end{array}$ & $\begin{array}{l}\text { Reference } \\
\text { centers }\end{array}$ & Shelters & $\begin{array}{l}\text { Exclusive } \\
\text { court of } \\
\text { domestic } \\
\text { violence }\end{array}$ & $\begin{array}{l}\text { Court of } \\
\text { domestic } \\
\text { violence }\end{array}$ & $\begin{array}{c}\text { Prosecutors } \\
\text { on } \\
\text { women's } \\
\text { issues }\end{array}$ & $\begin{array}{c}\text { Specialized } \\
\text { public } \\
\text { defense }\end{array}$ & $\begin{array}{l}\text { Forensic } \\
\text { services }\end{array}$ & $\begin{array}{c}\text { Health } \\
\text { specialized } \\
\text { facilities }\end{array}$ & $\begin{array}{c}\text { Health } \\
\text { facilities } \\
\text { with legal } \\
\text { abortion } \\
\text { services }\end{array}$ \\
\hline Acre & 20 & 10 & 5 & 2 & - & 1 & 2 & 1 & 2 & 6 & - \\
\hline Alagoas & 3 & - & 1 & 1 & 1 & - & 1 & 1 & 2 & 3 & - \\
\hline Amapá & 3 & 5 & 4 & 1 & 1 & - & 3 & 1 & 1 & 1 & - \\
\hline Amazonas & 1 & - & 3 & 1 & 2 & 1 & 2 & 1 & 1 & 7 & 2 \\
\hline Bahia & 15 & - & 19 & 2 & 2 & - & 1 & 3 & 1 & 10 & 2 \\
\hline Ceará & 7 & - & 16 & 2 & 2 & - & 5 & 1 & 2 & 31 & - \\
\hline Distrito Federal & 1 & - & 2 & 1 & 19 & - & 10 & 1 & 1 & 14 & 1 \\
\hline Espírito Santo & 10 & - & 6 & 3 & - & 4 & 1 & 1 & - & - & - \\
\hline Goiás & 21 & - & 11 & - & 2 & - & 2 & - & - & - & - \\
\hline Maranhão & 19 & - & 4 & 2 & 1 & 2 & 2 & 1 & 3 & 4 & - \\
\hline Mato Grosso & 6 & - & 2 & 4 & 4 & - & 4 & - & 1 & 1 & - \\
\hline $\begin{array}{l}\text { Mato Grosso do } \\
\text { Sul }\end{array}$ & 12 & - & 11 & 2 & - & 2 & 2 & 3 & - & 1 & - \\
\hline Minas Gerais & 51 & - & 15 & 5 & - & 3 & 5 & 8 & - & 9 & - \\
\hline Pará & 13 & - & 11 & 2 & - & 6 & 4 & 1 & 1 & 2 & 1 \\
\hline Paraíba & 9 & - & 4 & 2 & 2 & - & 2 & 1 & 2 & 8 & - \\
\hline Paraná & 17 & - & 6 & 5 & 2 & - & 1 & 1 & 18 & 2 & 1 \\
\hline Pernambuco & 8 & - & 12 & 6 & 3 & - & 1 & 1 & 3 & 4 & - \\
\hline Piauí & 7 & - & 1 & 2 & - & 1 & $\mathrm{~N} / \mathrm{A}$ & 1 & 1 & 7 & - \\
\hline Rio de Janeiro & 11 & - & 33 & 5 & 8 & - & - & 1 & - & 2 & 1 \\
\hline $\begin{array}{l}\text { Rio Grande do } \\
\text { Norte }\end{array}$ & 5 & - & 1 & 1 & 3 & - & $\mathrm{N} / \mathrm{A}$ & 2 & $\mathrm{~N} / \mathrm{A}$ & 2 & - \\
\hline
\end{tabular}




\begin{tabular}{|c|c|c|c|c|c|c|c|c|c|c|c|}
\hline Rio Grande do Sul & 15 & - & 22 & 11 & 1 & - & 3 & 1 & 3 & 5 & 4 \\
\hline Rondônia & 7 & - & 2 & 2 & 1 & - & 1 & 1 & 7 & 1 & - \\
\hline Roraima & 1 & - & 2 & 1 & 1 & 4 & - & 1 & 1 & 1 & - \\
\hline Santa Catarina & - & 28 & 4 & 5 & 4 & - & 1 & - & $\mathrm{N} / \mathrm{A}$ & 12 & - \\
\hline São Paulo & 129 & 0 & 29 & 14 & 1 & 7 & 0 & 0 & 0 & 288 & 24 \\
\hline Sergipe & 4 & & 1 & 1 & - & - & - & 1 & 1 & 1 & - \\
\hline Tocantins & 11 & - & 4 & 1 & - & 3 & 3 & 3 & 14 & 1 & - \\
\hline
\end{tabular}

Source: Brasil 2014. 